\begin{tabular}{l|l|l|l|l|}
$\begin{array}{l}\text { Journal of } \\
\text { Endocrinology }\end{array}$ & $\begin{array}{l}\text { J-P Fuller-Jackson and } \\
\text { B A Henry }\end{array}$ & $\begin{array}{l}\text { Thermogenesis and weight } \\
\text { change }\end{array}$ & $\mathbf{2 3 7 : 3}$ & R99-R115
\end{tabular}

REVIEW

\title{
Adipose and skeletal muscle thermogenesis: studies from large animals
}

\author{
John-Paul Fuller-Jackson and Belinda A Henry \\ Metabolism, Diabetes and Obesity Program, Monash Biomedicine Discovery Institute, Department of Physiology, Monash University, Clayton, \\ Victoria, Australia
}

Correspondence should be addressed to B A Henry: belinda.henry@monash.edu

\section{Abstract}

The balance between energy intake and energy expenditure establishes and preserves a 'set-point' body weight. The latter is comprised of three major components including metabolic rate, physical activity and thermogenesis. Thermogenesis is defined as the cellular dissipation of energy via heat production. This process has been extensively characterised in brown adipose tissue (BAT), wherein uncoupling protein 1 (UCP1) creates a proton leak across the inner mitochondrial membrane, diverting protons away from ATP synthesis and resulting in heat dissipation. In beige adipocytes and skeletal muscle, thermogenesis can occur independent of UCP1. Beige adipocytes have been

Key Words
- thermogenesis
D skeletal muscle
- adipose tissue
- weight loss
- obesity
- sheep
- pigs
shown to produce heat via UCP1 as well as via both futile creatine and calcium cycling pathways. On the other hand, the UCP1 homologue UCP3 is abundant in skeletal muscle and post-prandial thermogenesis has been associated with UCP3 and the futile calcium cycling. This review will focus on the differential contributions of adipose tissue and skeletal muscle in determining total thermogenic output and energy expenditure in large mammals. Sheep and pigs do not have a circumscribed brown fat depot but rather possess white fat depots that contain brown and beige adipocytes interspersed amongst white adipose tissue. This is representative of humans, where brown, beige and white adipocytes have been identified in the neck and supraclavicular regions. This review will describe the mechanisms of thermogenesis in pigs and sheep and the relative roles of skeletal muscle and adipose tissue thermogenesis in controlling body weight in larger mammals. 
It is widely recognised that body conformation is highly heritable and over 600 genes contribute to weight control (Perusse et al. 2005). It has been estimated that $40-70 \%$ of the innate variation in body mass index is determined by an individual's genetic background (Locke et al. 2015). Mutations in genes encoding various neuroendocrine factors including leptin, the leptin receptor, pro-opiomelanocortin (POMC), POMC posttranslational processing enzymes and the melanocortin 4 receptor $(M C 4 R)$ cause obesity in both humans and rodents (Jackson et al. 1997, Montague et al. 1997, Clement et al. 1998, Krude et al. 1998, Farooqi et al. 2003). Despite this, monogenetic mutations are extremely rare (Farooqi 2008). To add further complexity, preconception and early life environments impact on body mass via epigenetic modifications (Lillycrop \& Burdge 2010) such as those to the tripartite motif-containing 28 (TRIM28) gene, which correlates with increased adiposity in humans (Dalgaard et al. 2016). Dogma now stipulates that various genetic and epigenetic factors lead to inherent susceptibility to become obese, which is typically unmasked by environmental pressure. Irrespective of this, it is well recognised that, once obese, it is extremely difficult to lose weight and maintain weight loss, due to homeostatic defence mechanisms that reset hunger and energy expenditure.

Early weight loss trials suggested that only $2 \%$ of the population could maintain long-term weight loss, at the two-year time point, in response to diet and exercise interventions (Stunkard \& McLaren-Hume 1959). Successful weight loss is defined as $>10 \%$ reduction in body weight, which is maintained for 1 year (Wing \& Hill 2001, Wing \& Phelan 2005). Numerous endocrine and neuroendocrine adaptations occur in response to weight loss, driving increased hunger and reduced energy expenditure (Lewis et al. 1993, Bi et al. 2003, $\mathrm{Yu}$ et al. 2009, Sumithran et al. 2011). In response to weight loss, circulating levels of the gut-derived appetitestimulating hormone ghrelin are increased, whereas satiety factors such as leptin, amylin, cholecystokinin and glucagon-like peptide 1 are decreased (Sumithran et al. 2011). Importantly, this maladaptation in the secretion of numerous endocrine factors persists for up to 2 years post-weight loss (Sumithran et al. 2011). The aforementioned endocrine factors exert reciprocal effects on food intake and energy expenditure, where hormones that increase food intake typically reduce energy expenditure and vice versa (Kirchner et al. 2012, Park \& Ahima 2015, Bauer et al. 2016). Thus, weightloss-induced changes in circulating factors not only act to increase hunger but exert a dual effect to reduce energy expenditure, which predisposes individuals to regain lost weight (Leibel et al. 1995, Ravussin et al. 1988, Bosy-Westphal et al. 2013). A key component of the decrease in energy expenditure is reduced adaptive thermogenesis (Rosenbaum et al. 2008, Camps et al. 2015, Henry et al. 2017), which occurs in both skeletal muscle and brown adipose tissue (BAT). To investigate the specific metabolic adaptations that underlie these changes in thermogenesis at the tissue and molecular level, it is pertinent to use animal models. Rodents including mice, rats and hamsters have provided invaluable information to this field with widespread use of transgenic, optogenetic and knockout models (Lutz \& Woods 2012, Barrett et al. 2016). The current review, however, will focus on metabolic flexibility of genetically heterogeneous or outbred populations of large animals, specifically sheep (Ovis aries) and pigs (Sus) and the role of thermogenesis in innate predisposition to obesity or inherent resistance to diet-induced weight loss.

\section{Mechanisms of thermogenesis}

\section{Brown adipose tissue}

Body weight is determined by the balance between energy intake and energy expenditure, with the latter comprised of basal metabolic rate, physical activity and adaptive thermogenesis. Adaptive thermogenesis is defined as specialised heat production and occurs in BAT and skeletal muscle. Cold- and meal-associated stimuli are perceived by the brain, leading to activation of the sympathetic nervous system (SNS) and the induction of thermogenesis (Lowell \& Spiegelman 2000, Cannon $\&$ Nedergaard 2004). Noradrenaline is released within BAT and activates uncoupling protein 1 (UCP1), which creates a proton leak across the inner mitochondrial membrane. This proton leak redirects protons away from ATP synthase and the production of ATP; cellular energy is dissipated in the form of heat (Fig. 1) (Cannon $\&$ Nedergaard 2004).

Across the lifespan, mice and rats retain a defined and circumscribed brown fat depot located in the interscapular region (Sbarbati et al. 1991, Morroni et al. 1995). This contrasts with larger adult mammals, including humans and sheep, where brown adipocytes are interspersed amongst white adipose tissue (WAT) (Cypess et al. 2013, Henry et al. 2017). Indeed, for many years, dogma stipulated that in humans BAT was only abundant during early life, 


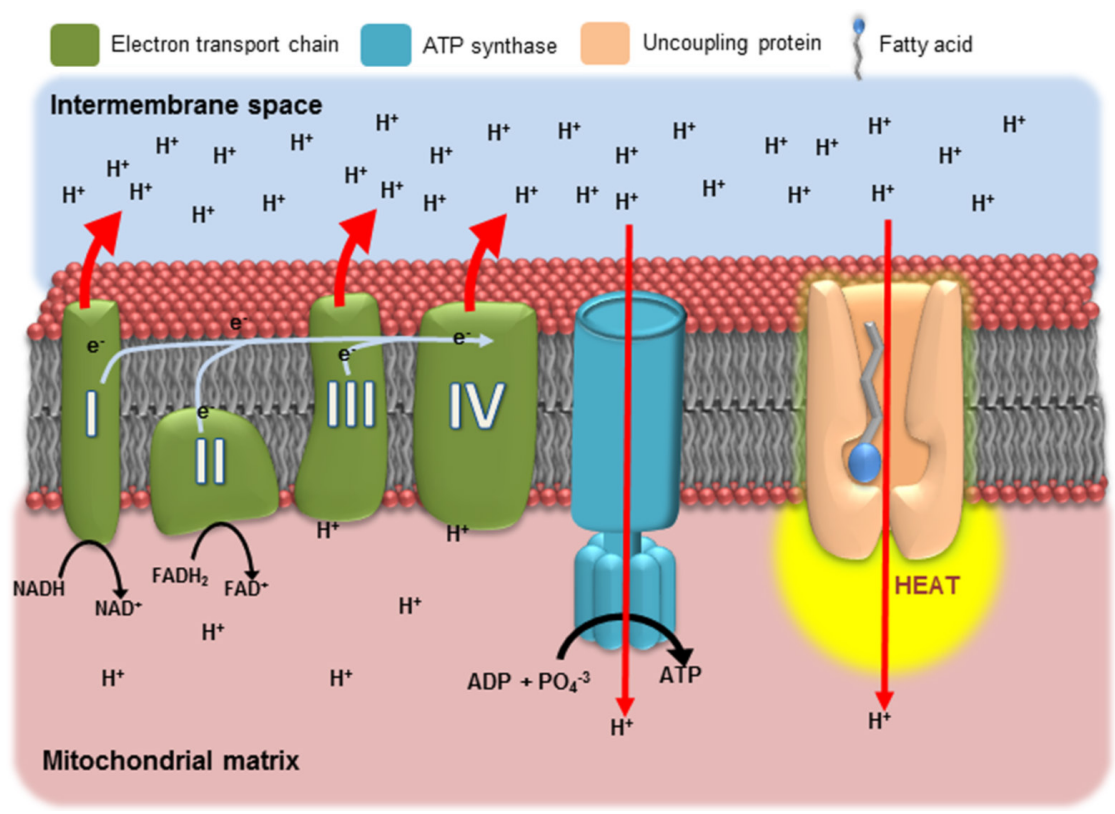

\section{Figure 1}

Schematic of mitochondrial uncoupling and the cellular process of thermogenesis. Metabolic processes such as glycolysis, $\beta$-oxidation and the citric acid cycle contribute electrons through the nicotinamide adenine dinucleotide $\left(\mathrm{NAD}^{+}\right)$and flavin adenine dinucleotide ( $\left.F A D^{+}\right)$carriers to the electron transport chain. The action of the electron transport chain (complexes I-IV) results in the pumping of protons across the inner mitochondrial membrane from the matrix into the intermembrane space and the establishment of the electrochemical gradient. Normally, this proton motive force is harnessed by ATP synthase to produce ATP from ADP. UCPs provide an alternative means through which protons can cross the inner membrane. Fatty acids activate UCPs by binding to a hydrophobic pocket within the protein that increases proton conductance. The leak of protons across the inner mitochondrial membrane results in the dissipation of energy through heat production. being fundamental to maintaining core body temperature in neonates (Aherne \& Hull 1966, Heaton 1972, Cannon $\&$ Nedergaard 2004). Soon after birth, muscle acquires the ability to provide heat through shivering and thus BAT levels rapidly decline and were thought to be negligible in adult humans (Cunningham et al. 1985, Astrup 1986). A series of landmark papers have since identified pockets or islands of BAT particularly within the neck and supraclavicular region of adults (Nedergaard et al. 2007, Cypess et al. 2009, van Marken Lichtenbelt et al. 2009). These depots not only contain brown and white adipocytes, but also the morphologically distinct beige adipocytes (discussed in detail in the following section) (Sharp et al. 2012, Cypess et al. 2013, Jespersen et al. 2013, Nedergaard \& Cannon 2013, Lee et al. 2014a). Functional BAT has since been observed in epicardial, paravertebral and perirenal adipose tissues (Cypess et al. 2015, Gaborit et al. 2015), although the physiological relevance of these depots to energy homeostasis remains to be elucidated.

\section{Skeletal muscle}

In addition to BAT, skeletal muscle is thermogenic, which occurs independent of UCP1. Myocytes express the $U C P 1$ homologue, UCP3, which is capable of uncoupling oxidative phosphorylation in mitochondria isolated from yeast cells (Gong et al. 1997). In addition to mitochondrial uncoupling, skeletal muscle produces heat via futile calcium cycling (Simonides et al. 2001, de Meis et al. 2005, Arruda et al. 2007, Clarke et al. 2012, Blondin et al. 2017) where calcium exits the sarcoendoplasmic reticulum (SR) via the ryanodine receptor (RyR). To maintain cytosolic calcium levels, activation of the sarcoendoplasmic reticulum ATPases (SERCA) propel calcium back into the SR; this effect is driven by the hydrolysis of ATP and results in heat production (Arruda et al. 2007, Bal et al. 2012) (Fig. 2). In rodents, sarcolipin is an endogenous activator of SERCA, which uncouples calcium transport from the hydrolysis of ATP, leading to an increase in the futile cycling of calcium and heat production (Fig. 2). In the absence of BAT (surgical removal) or UCP1 (genetic deletion), sarcolipin increases muscle thermogenesis and is essential for cold adaptation (Bal et al. 2012, 2016). Over-expression of sarcolipin in skeletal muscle increases oxygen consumption and fatty acid oxidation, which is associated with resistance to weight gain in mice fed a high fat diet (Maurya et al. 2015). The role of sarcolipin in thermogenesis in larger mammals, however, is relatively unexplored and requires closer investigation. Given that skeletal muscle accounts for approximately $40 \%$ of total body mass, it is hypothesised that, at least in large mammals, even small differences in muscle thermogenesis may contribute substantially to thermogenic capacity and total energy expenditure. Indeed, earlier work in adult humans suggested that skeletal muscle was the primary means of thermogenesis in response to sympathomimetic treatment (Astrup et al. 1985, Astrup 1986); ephedrine-induced thermogenesis is 10 fold higher in skeletal muscle than adipose tissue. It is important to emphasise, however, that this earlier work did not study adipose tissue in the neck and clavicular regions, where 


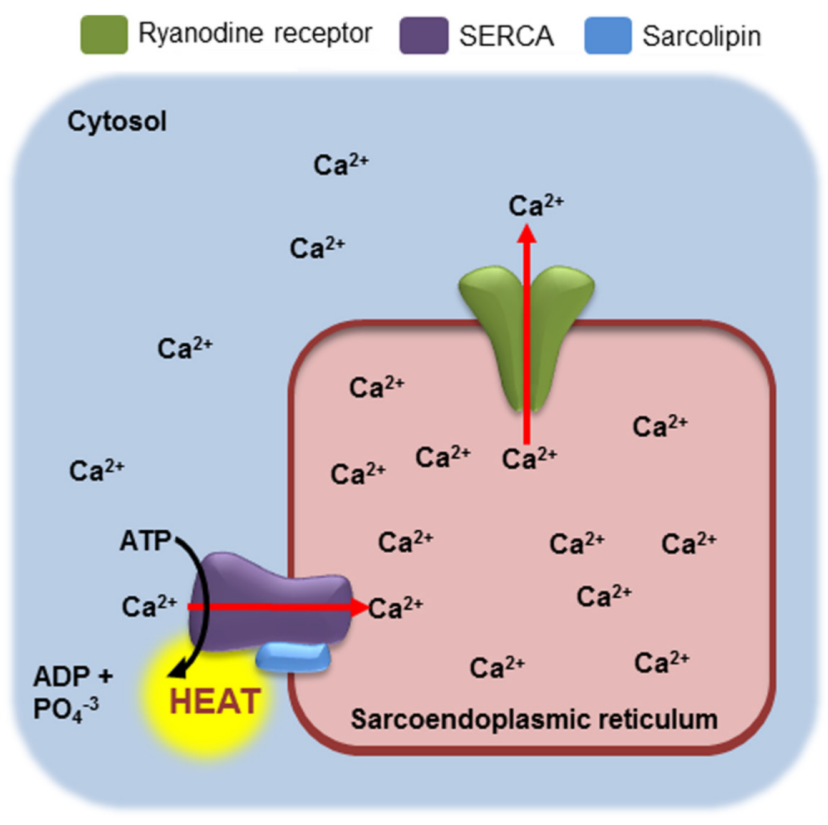

Figure 2

Schematic representation of futile calcium-cycling-mediated thermogenesis. At rest, the passive leak of calcium from the sarcoendoplasmic reticulum (SR) occurs via the ryanodine receptor. To maintain intracellular calcium homeostasis, calcium is propelled back into the SR via the sarcoendoplasmic reticulum ATPase (SERCA) pump. The movement of calcium against the concentration gradient requires the hydrolysis of ATP, which is thermogenic and produces heat. Sarcolipin is a key regulator of SERCA and activates thermogenesis via the futile calcium pathway.

brown/beige adipocytes are most abundant. Nonetheless, PET-CT studies in lean humans show that chronic low dose ephedrine treatment actually reduces BAT activity (Carey et al. 2015), which strongly suggests that tissues such as a skeletal muscle are important in whole body thermogenesis in humans.

On the other hand, the contribution of skeletal muscle to cold-induced adaptive thermogenesis in humans remains unclear. In obese and lean subjects, BAT is activated by cold exposure (Saito et al. 2009, van Marken Lichtenbelt et al. 2009, Wijers et al. 2010). In BAT, cold exposure increases UCP1 levels with a concomitant increase in BAT activity, whereas in skeletal muscle there is no effect of cold on the expression of UCP3. Despite this, in lean men, cold exposure increases uncoupled respiration in permeabilised muscle fibres, which correlates with total energy expenditure (Wijers et al. 2008). Furthermore, in humans, skeletal muscle accounts for the vast majority of increased glucose uptake and utilisation during cold exposure compared to BAT (Blondin et al. 2015). A recent study, however, suggests that after 4 weeks of cold exposure, muscle-derived adaptive non-shivering thermogenesis is inhibited in favour of BAT thermogenesis (Blondin et al. 2017). This increase in BAT thermogenic capacity obviates the need for increased adaptive thermogenesis in skeletal muscle. Irrespective of the role of skeletal muscle in long-term cold adaptation, current evidence supports the notion that skeletal muscle is an important determinant of thermogenic capacity and contributes to total energy expenditure in adult humans.

\section{Beige adipocytes}

As alluded to above, adipose tissue is heterogeneous, containing numerous cell types. White adipocytes are unilocular, containing one large lipid droplet and few mitochondria, whereas brown adipocytes are multilocular and have numerous mitochondria (Cousin et al. 1992, Cinti 2001, Barbatelli et al. 2010). More recently, a third adipocyte, the beige cell has been identified (HimmsHagen et al. 2000, Barbatelli et al. 2010). Beige adipocytes exhibit an intermediary phenotype and are referred to as paucilocular, as these cells contain more than one lipid droplet and multiple mitochondria (Himms-Hagen et al. 2000, Barbatelli et al. 2010). Beige adipocytes also express UCP1 and have been termed 'recruitable' as these cells can be detected in small clusters within WAT in response to certain stimuli, such as cold (Shabalina et al. 2013, Lee et al. 2014a, Jankovic et al. 2015). Brown and beige adipocytes display distinct genetic fingerprints and importantly unlike brown adipocytes that show high basal expression of thermogenic genes such as UCP1, beige adipocytes only exhibit these genes in response to activating stimuli including cold and $\beta$-adrenoceptor agonists (Walden et al. 2012, Wu et al. 2012, Rosenwald et al. 2013). Furthermore, unlike brown adipocytes, which are derived from Myf5 +ve precursor cells, beige adipocytes are derived from bipotent preadipocytes (Seale et al. 2008, Sanchez-Gurmaches et al. 2012, Harms \& Seale 2013, Wang et al. 2013). The beige cell represents a novel adipocyte that contributes to thermogenesis in both rodents and humans (Cohen \& Spiegelman 2015).

In addition to UCP1-dependent thermogenesis, beige adipocytes produce heat through futile creatine (Fig. 3) (Kazak et al. 2015, Bertholet et al. 2017) and futile calcium cycling pathways (Ikeda et al. 2017) (Fig. 2). In mice, proteomic analyses revealed a beige adipocyte-specific arginine-creatine metabolic pathway (Kazak et al. 2015), which is upregulated in response to cold exposure. Futile creatine cycling is important in 


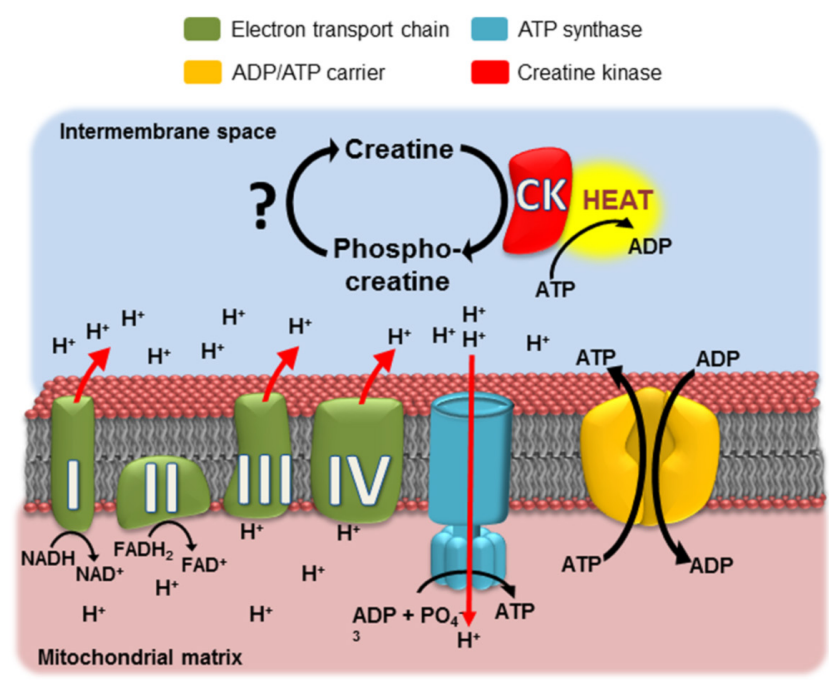

Figure 3

Schematic diagram depicting the futile creatine cycle. Within mitochondria, thermogenesis can occur in the ADP-depleted state via creatine cycling. Creatine is phosphorylated by creatine kinase (CK) and then dephosphorylated. The responsible phosphatase is currently unidentified. The process of creatine dephosphorylation is thermogenic via the hydrolysis of ATP.

beige adipocyte thermogenesis in ADP-depleted states, wherein this pathway drives the hydrolysis of ATP and thus increases oxygen consumption (Kazak et al. 2015). Cold exposure for 1 week increased the expression of both creatine kinase U-type, mitochondrial (Ckmt1) and creatine kinase S-type, mitochondrial (Ckmt2) in inguinal beige adipocytes, indicative of an upregulation in creatine cycling. Furthermore, treatment with the $\beta 3$-adrenoceptor agonist, CL316 234, induced Ucp1-expressing beige adipocytes in the inguinal fat depot, as well as Ucp1negative, Ckmt2-positive beige adipocytes in epididymal fat (Bertholet et al. 2017). Murine beige adipocytes also produce heat via futile calcium cycling and the activation of SERCA2b (Ikeda et al. 2017). Inhibition or downregulation of SERCA2b in inguinal adipose tissue attenuates the noradrenaline-induced increase in oxygen consumption (Ikeda et al. 2017), supporting the notion that futile calcium cycling is important in sympatheticinduced thermogenesis in beige adipocytes. To date, the vast majority of studies have utilised UCP1 protein or mRNA expression as a marker for beige adipocytes, and thus the abundance and importance of these cells have likely been underestimated. It is now apparent that multiple pathways contribute to thermogenesis in these unique beige cells. The role of beige adipocytes in determining thermogenesis and energy expenditure in larger mammals including sheep and pigs, however, requires further interrogation.

\section{Neuroendocrine control of energy balance}

Control of adaptive thermogenesis is mediated by the hypothalamus, and while only explained briefly here, has been well detailed by Morrison (Morrison 2016). In rodents, when exposed to cold, thermosensory inputs act via the median preoptic area to stimulate the dorsomedial hypothalamus (DMH) to increase sympathetic nerve activity to BAT through the rostral raphe pallidus (rRPa) (Hermann et al. 1997, Yoshida et al. 2009, Yu et al. 2016). Earlier work identified a subset of cold-inhibited and warm-activated GABA-containing neurons within the preoptic area that mediate coldinduced thermogenesis (Nakamura \& Morrison 2007). Development of Designer Receptor Exclusivity Activated by Designer Drugs (DREADD) technology has allowed for further characterisation of these temperature-sensitive neurons. Use of DREADDS suggests that activation of GABA neurons in the preoptic area has little effect on body temperature or energy expenditure ( $\mathrm{Yu}$ et al. 2016). Indeed, these studies show that leptin-receptorexpressing neurons in the preoptic area are integral to ambient temperature-induced metabolic (food intake and energy expenditure) adaptations (Yu et al. 2016). Within the preoptic area, there is clearly topographical neuronal organisation as cold exposure increases c-Fos levels in GABA neurons within the ventral part of the lateral preoptic area (Zhao et al. 2017) and optogenetic manipulation of these neurons influences body temperature. Optogenetic inhibition of this subset of GABA neurons causes hyperthermia, whereas activation of the same reduces body temperature (Zhao et al. 2017). Thus, within the preoptic area, there is an integrated network of neurons, including both GABA-ergic and leptin responsive cells, capable of sensing changes in skin temperature and modifying thermogenic output.

In addition to the aforementioned temperaturesensitive pathway, metabolic factors such as leptin, insulin and ghrelin modulate thermogenic activity via hypothalamic appetite-regulating peptides. Bloodborne factors can diffuse across the blood brain barrier via fenestrated capillaries and act directly on neurons in the arcuate nucleus (Banks 2009). The diffusion of metabolic hormones is controlled by local tanycytes (Balland \& Cowley 2017). Importantly, two distinct sets of neurons are found in the arcuate nucleus, being either orexigenic or those that elicit satiety. The POMC neurons are activated by leptin (Elias et al. 1999, Cowley et al. 2001) and insulin (Claret et al. 2007, Williams et al. 2010), leading to release of $\alpha$-melanocyte-stimulating 
hormone (aMSH), which elicits satiety via the MC4R in the paraventricular nucleus (PVN) (Cowley et al. 1999, Balthasar et al. 2005). A second population of neurons contain neuropeptide $\mathrm{Y}$ (NPY) and agouti-related protein (AgRP), which stimulate food intake in response to direct stimulation by ghrelin (Kamegai et al. 2001). The primary role of NPY/AgRP neurons is to protect against starvation; genetic deletion of $A g R P$ reduces food intake and causes wasting, eventually leading to starvation and death (Luquet et al. 2005). NPY exerts an immediate effect to stimulate food intake, primarily via action at $\mathrm{Y} 1$ receptors in the PVN (Kask et al. 1998). On the other hand, AgRP acts as an inverse agonist at the MC4R to stimulate food intake (Nijenhuis et al. 2001). Hypothalamic appetite-regulating peptides exert reciprocal control to modulate food intake and energy expenditure, in particular BAT and muscle thermogenesis (Verty et al. 2010, Gavini et al. 2016). Indeed, pseudorabies-tracing studies show that appetite-regulating neurons of the hypothalamus ultimately project to neural networks controlling sympathetic outflow to peripheral tissues including BAT (Bamshad et al. 1999, Oldfield et al. 2002, Song et al. 2009, Ryu et al. 2015).

As mentioned earlier, activation of the SNS and the release of catecholamines, in particular, noradrenaline are fundamental to BAT thermogenesis. Indeed, genetic deletion of all three $\beta$-adrenergic receptors ( $\beta A R$ ) in brown adipocytes of mice causes profound obesity by negating thermogenesis (Bachman et al. 2002). Interestingly, in humans, isoprenaline (a non-specific $\beta A R$ ) treatment increases energy expenditure without an associated activation of BAT (Vosselman et al. 2012). Similarly, blockade of the $\beta A R$ with propranolol had no effect on cold-induced BAT thermogenesis in humans (Wijers et al. 2011). This lack of effect, however, is likely due to receptor specificity as both isoprenaline and propranolol show preferential agonistic and antagonistic affinity to the $\beta 1 \mathrm{AR}$ and $\beta 2 \mathrm{AR}$, respectively. Indeed, in healthy lean men, administration of the $\beta 3$ AR-specific agonist, mirabregon, activates BAT and causes a concurrent increase in resting metabolic rate (Cypess et al. 2015). Furthermore, a $64 \mathrm{Trp} / \mathrm{Arg}$ genetic polymorphism in the $\beta 3 \mathrm{AR}$ is linked to the decline in BAT function with ageing in men (Yoneshiro et al. 2012). Together, these studies highlight that in humans, the $\beta 3 \mathrm{AR}$ is essential to catecholamine-mediated BAT thermogenesis. It remains possible, however, that the effects of isoprenaline to increase energy expenditure via the $\beta 1 / \beta 2 \mathrm{AR}$ (Vosselman et al. 2012) are mediated via skeletal muscle thermogenesis (Blaak et al. 1993).
In addition to catecholamines, thyroid hormones (TH) are notable endocrine regulators of BAT activity. Brown adipocytes contain the deiodinase type 2 (DIO2) enzyme, allowing for local conversion of thyroxine (T4) to triiodothyronine (T3) (Carvalho et al. 1991); T3 exhibits greater biological potency than $\mathrm{T} 4$. In rodents, $\mathrm{TH}$ act directly at nuclear thyroid hormone receptors located in brown adipocytes to transcriptionally upregulate UCP1 expression (Weiner et al. 2017). Furthermore, clinical data demonstrate that BAT activity is higher in the subclinical hyperthyroid state than in the hypothyroid state (Broeders et al. 2016), supporting the notion that endogenous TH regulate BAT thermogenesis. Although the classical action of $\mathrm{T} 3$ is thought to be peripherally mediated, more recent studies have shown that TH can also act centrally within the hypothalamus to regulate BAT thermogenesis. Tanycytes in the mediobasal hypothalamus express $\mathrm{DIO} 2$ and thus convert $\mathrm{T} 4$ to T3 (Coppola et al. 2007). Furthermore, in mice, intracerebroventricular administration of $\mathrm{T} 3$ increases BAT thermogenesis via reduced hypothalamic levels of AMP kinase (AMPK) and subsequent activation of the SNS (Lopez et al. 2010). Indeed, sub-chronic (6 days) central administration of T3 leads to browning of WAT in mice (Alvarez-Crespo et al. 2016).

To date, much of the work defining the regulation of thermogenesis and its contribution to energy balance has been in rodents. This has provided invaluable information and understanding of the neuroendocrine mechanisms that control thermogenesis. More recently, a number of large animal models have been employed including pigs and sheep, which provide further insight into the role of thermogenesis in long-term regulation of body weight in mammalian species.

\section{Regulation and significance of thermogenesis in pigs}

It is well recognised that pigs lack a functional UCP1 protein (Hou et al. 2017), which previously led to the assumption that this species did not possess brown adipocytes. Pigs, specifically those belonging to the Suidae species, do not have exons 3-5 of the UCP1 gene, rendering animals prone to hypothermia-induced death as neonates (Berg et al. 2006). With only exons 1 and 2, UCP1 can still be transcribed; however, protein translation does not occur (Hou et al. 2017). Hence, previous histological studies failed to detect UCP1 protein immunoreactivity at baseline (Rowlatt et al. 1971) or in response to cold 
exposure (Trayhurn et al. 1989), and thus pigs were deemed to be lacking BAT. It has since been proposed that pigs do indeed possess functional BAT; however, adaptive thermogenesis occurs via UCP1-independent mechanisms (Ikeda et al. 2017, Lin et al. 2017). Indeed, recent work comparing cold-tolerant Tibetan pigs to cold-sensitive Bama pigs has provided direct evidence of adaptive thermogenesis in subcutaneous (sWAT) and perirenal WAT (Lin et al. 2017) (Fig. 4). Both of these pig breeds lack UCP1 expression, yet when subjected to cold exposure $\left(4^{\circ} \mathrm{C}\right.$ for $\left.4 \mathrm{~h}\right)$ PET-CT identified metabolically active subcutaneous and perirenal adipose tissue (Lin et al. 2017) in cold-tolerant animals, which contributed to the maintenance of core body temperature. Furthermore, morphological studies show that in response to cold exposure, subcutaneous adipose tissue displays evidence for beige cell recruitment with an increase in multilocular adipocytes, increased mitochondrial DNA copy number and increased expression of PGC1a and the beige cell marker CD137 (Wu et al. 2012, Lin et al. 2017). Furthermore, in Tibetan pigs (cold tolerant), cold exposure increased the expression of the UCP3 gene and protein in isolated subcutaneous adipocytes and this is associated with increased uncoupled respiration, providing evidence to suggest an increase in UCP3-driven thermogenesis (Lin et al. 2017) (Fig. 4).

The contribution of UCP3 to brown fat thermogenesis has been contentious and appears to be dependent on the species studied. In mice, earlier work suggested that BAT thermogenesis was dependent on UCP1 (Matthias et al. 2000). Despite this, hamsters that lack functional UCP3 specifically in brown adipocytes have increased propensity to weight gain, which is indicative of a reduction in energy expenditure (Fromme et al. 2009). Although innate differences in UCP3 expression in adipose tissue of pigs have been linked to cold tolerance, to date, there are no data on BAT-specific UCP3 function and the control of body weight in this species.

In addition to UCP3-associated uncoupling and thermogenesis, recent data suggest that SERCA-driven beige cell thermogenesis also occurs in pigs. Indeed, the work by Ikeda et al. (Ikeda et al. 2017) demonstrate strong conservation of the beige adipocyte SERCA2b pathway across species. Retroviral expression of PRDM16 in subcutaneous porcine adipocytes increases the expression of beige-cell-specific markers including CIDEA and TMEM26 (Ikeda et al. 2017). Furthermore, decreased $S E R C A 2 b$ expression reduced basal and noradrenalineinduced oxygen consumption and extracellular acidification rates in isolated pig adipocytes (Ikeda et al. 2017). Thus, it is now clear that adipose tissue thermogenesis and the associated energy expenditure are not solely mediated via UCP1 and mitochondrial uncoupling, but in fact, a number of cellular pathways, across both adipose tissue and skeletal muscle, act in concert to determine total thermogenic potential.

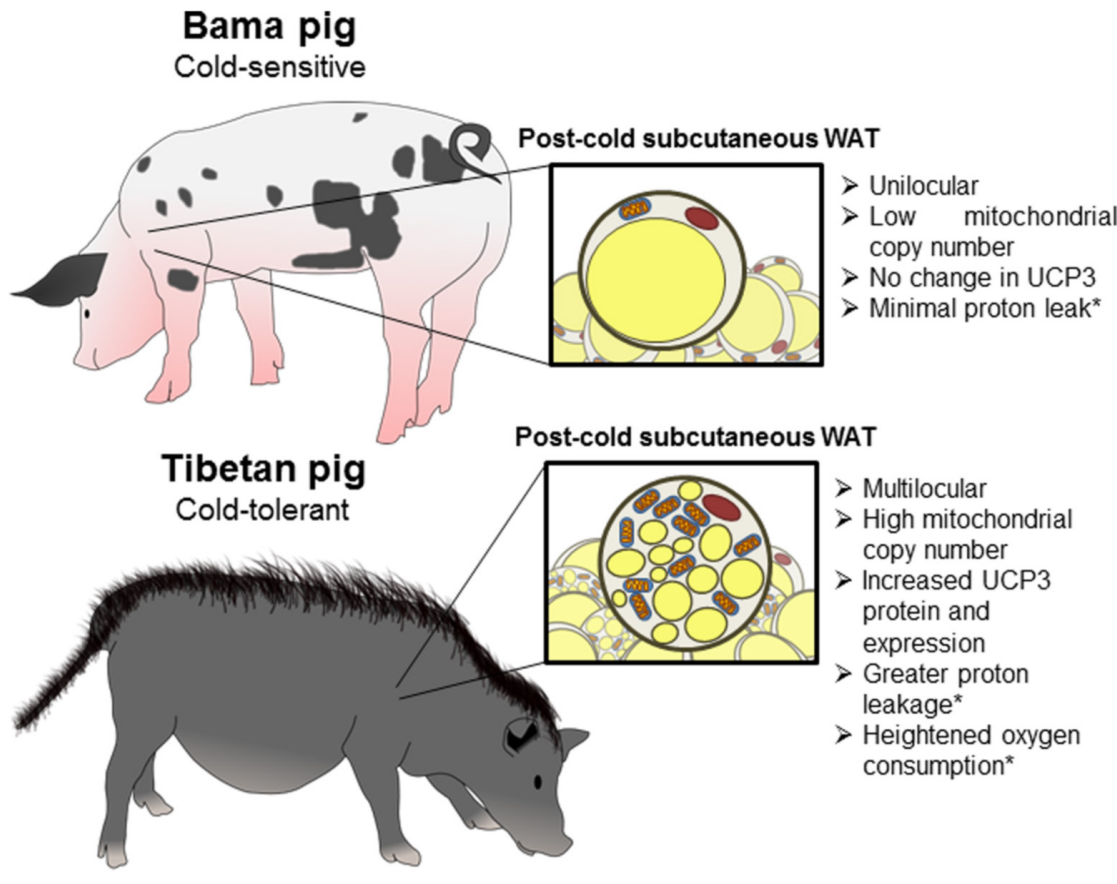

*in beige adipocytes differentiated from primary adipocytes of subcutaneous WAT.

\section{Figure 4}

Role of thermogenesis in determining cold tolerance in pigs. Tibetan pigs are cold tolerant and this coincides with the recruitment of beige adipocytes in subcutaneous WAT in response to cold exposure. Although pigs do not that express functional uncoupling protein (UCP) 1, adipocytes exhibit UCP3 and this mediates mitochondrial uncoupling and adipose tissue thermogenesis. In contrast the Bama pig is unable to induce 'browning' in WAT of white adipose tissue and thus is characterized as cold sensitive. *Denotes findings from beige adipocytes differentiated from primary adipocytes of subcutaneous WAT. 


\section{Role of thermogenesis in sheep}

In lambs, the expression of $U C P 1$ is maximal in perirenal adipose tissue on the first postnatal day, rapidly declining with the expansion of WAT (Symonds 2013, Pope et al. 2014). Mapping of UCP1 mRNA in lambs shows abundant expression in sternal and retroperitoneal adipose depots compared to omental fat, which is a predominantly WAT depot (Symonds et al. 2012). Indeed, adult sheep retain UCP1 expression in both sternal and retroperitoneal fat and this coincides with post-prandial heat production, albeit this response is greater in the sternal fat depot (Henry et al. 2017). This coincides with the expression of UCP1 protein, where UCP1-positive brown-like adipocytes were only detectable in sternal adipose tissue of adult ewes (Henry et al. 2017). Data logger temperature probes have been employed to measure longitudinal heat production in multiple tissues to index thermogenic output in sheep. Sheep are a grazing species and therefore do not display typical meal-associated excursions such as changes in ghrelin secretion. Despite this, temporal food restriction in sheep entrains a pre-prandial rise in ghrelin (Sugino et al. 2002, Takahashi et al. 2008) and postprandial increases in thermogenesis in skeletal muscle and adipose tissue (Henry et al. 2008, 2017), similar to what is seen in humans (Johnston et al. 2002, Stob et al. 2007, van Baak 2008). In adult sheep, post-prandial skeletal muscle thermogenesis is associated with increased expression of UCP3 as well as an increase in protein and/or gene expression of markers of futile calcium cycling (Clarke et al. 2012). Furthermore, post-prandial thermogenesis in both skeletal muscle and retroperitoneal adipose depots is markedly enhanced by intracerebroventricular infusion of leptin (Henry et al. 2008). Thus, in spite of relatively low levels of UCP1 in adult sheep, skeletal muscle and specific adipose depots retain thermogenic capacity. Over recent years, we have utilised the sheep to dissect the differential roles of adipose tissue and skeletal muscle thermogenesis in the long-term control of body weight, which is discussed in detail in the following section.

\section{Role of thermogenesis in controlling long-term changes of body weight in sheep}

Similar to other species, ovine body weight can be readily manipulated through dietary management (Henry et al. 2000, 2017, Iqbal et al. 2001, 2003). Sheep are ruminants and thus body weight is increased through feeding a highenergy diet enriched in lupin grain and oats. Diet-induced obesity, however, is not associated with any change in heat production in adipose tissues or skeletal muscle of sheep (Henry et al. 2017). On the other hand, long-term food restriction and low body weight are associated with a homeostatic decrease in thermogenesis in sternal and retroperitoneal adipose tissue and skeletal muscle (Henry et al. 2017) (Fig. 5). Importantly, similar to humans, the reduction in thermogenesis caused by food restriction and low body weight is still evident at one year postweight loss, which suggests that homeostatic changes in thermogenesis contribute to impaired weight loss and increased long-term weight regain (Henry et al. 2017).

The homeostatic reduction in thermogenesis is coordinated by the hypothalamus. Long-term weight loss in ovariectomised ewes increases the expression of the orexigenic neuropeptides NPY in the arcuate nucleus and melanin-concentrating hormone $(\mathrm{MCH})$ in the lateral hypothalamus (LH) to increase hunger and reduce energy expenditure (Henry et al. 2000) (Fig. 5). Regarding the anorexigenic melanocortin pathway, the effect of low body weight on the expression of POMC is controversial with data showing a decrease (Backholer et al. 2010) or no effect (Henry et al. 2000). This is not surprising since POMC is the precursor to multiple neuropeptides, only one of which includes aMSH and the ultimate end product is dependent on post-translational processing (Mountjoy 2010). On the other hand, increased Agrp and Npy

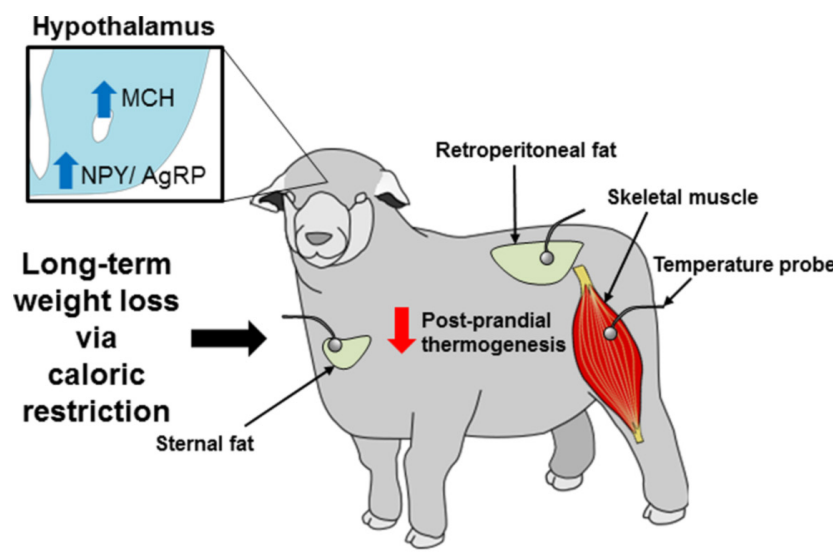

RESULT: Hunger $\downarrow$ Energy expenditure

\section{Figure 5}

Effect of chronic food restriction and weight loss on adaptive thermogenesis in ewes. Tissue temperature recordings show that caloric restriction and low body weight cause a homeostatic decrease in night time thermogenesis in ovariectomised ewes. This metabolic adaptation occurs in both sternal adipose tissue (adipose tissue enriched in uncoupling protein 1) and skeletal muscle and to a lesser extent in retroperitoneal adipose tissue. The reduction in thermogenesis is associated with increased expression of neuropeptide $Y$ (NPY) in the arcuate nucleus and melanin-concentrating hormone $(\mathrm{MCH})$ in the lateral hypothalamus. 
expression and reduced Pomc mRNA have been observed in rodents (Bi et al. 2003, Rogers et al. 2016) and lambs (McShane et al. 1993). Thus, weight-loss-induced changes in hypothalamic gene expression are likely to reduce thermogenesis, whilst causing a concurrent increase in hunger drive. This represents a homeostatic mechanism to protect against weight loss and promote weight regain in calorie-restricted individuals.

\section{Polygenic models of predisposition to obesity in sheep}

Over thousands of years of domestication, the modern sheep has undergone much human-imposed selection to the point that there exists polygenic populations predisposed to either obesity or leanness (Afonso \& Thompson 1996, Morris et al. 1997). Animals were originally selected for innate differences in adiposity by measuring back fat thickness and two lines were created via selective breeding strategies. A key feature of the genetically lean and obese sheep is an inherent difference in the growth hormone (GH) axis, where lean animals have increased mean GH concentration in plasma and an associated increase in pituitary gland weight (Francis et al. 1998). The increase in pituitary gland weight is primarily due to a greater number of cells in the lean animals (Francis et al. 2000). Furthermore, expression of $G H$ and the GH secretagogue receptor (GHSR) is greater in genetically lean sheep, indicating differential responses to ghrelin, an agonist of the GHSR (French et al. 2006). This suggests that innate differences in the set-point of the GH axis may underpin differences in adiposity in the genetically lean and obese sheep; however, this is only one aspect that could contribute to this phenotype.

Interestingly, food intake is similar in genetically lean and obese sheep as is the expression of POMC, Leptin Receptor and NPY in the arcuate nucleus. On the other hand, lean animals have elevated post-prandial thermogenesis in retroperitoneal adipose tissue and this coincides with increased expression of UCP1 in this tissue (Henry et al. 2015). The divergence in thermogenesis is specific to adipose tissue since post-prandial thermogenesis is similar in genetically lean and obese animals (Henry et al. 2015). Despite similar expression of appetite-regulating peptides in the arcuate nucleus of the hypothalamus, genetically lean sheep have increased expression of $\mathrm{MCH}$ and pre-pro-orexin $(\mathrm{ORX})$ in the $\mathrm{LH}$ compared to obese animals (Anukulkitch et al. 2010). While both neuropeptides are considered orexigenic (Shimada et al. 1998, Hara et al. 2001, Ito et al. 2003,
Segal-Lieberman et al. 2003), MCH and orexin have differing effects on energy expenditure (Teske et al. 2008). Deletion of $M C H$ in mice results in hypophagia and a lean phenotype (Shimada et al. 1998), while deletion of ORX leads to obesity despite also causing hypophagia (Hara et al. 2001). Orexin is critical in the embryonic development of BAT in mice (Sellayah et al. 2011), and loss of orexin neurons impairs stress- (Zhang et al. 2010) and cold-induced thermogenesis (Mohammed et al. 2016). Thus, increased expression of ORX in the LH of lean sheep may be an important physiological determinant of increased thermogenesis in retroperitoneal fat and the associated changes in adiposity.

The stress axis, cortisol responsiveness and obesity in sheep

It is widely recognised that there is marked variation in the glucocorticoid response to stress or activation of the hypothalamo-pituitary adrenal (HPA) axis (Cockrem 2013, Walker et al. 2017). The activity of the HPA axis in response to stress is impacted on by age (Sapolsky et al. 1986a,b, Turner et al. 2010), pregnancy (Brunton \& Russell 2011), lactation (Tilbrook \& Clarke 2006), sex (Turner et al. 2010) and sex steroids (Turner et al. 2002, 2006). Nonetheless, in any given population individuals can be characterised as either high (HR) or low (LR) glucocorticoid responders (Epel et al. 2001, Newman et al. 2007, Knott et al. 2008, Touma et al. 2008, Lee et al. 2014b). It is important to note that female LR and HR sheep have similar basal plasma cortisol concentration and divergence in glucocorticoid secretion only occurs in response to ACTH or stress (Lee et al. 2014c, Hewagalamulage et al. 2016). Previous studies have suggested that obesity itself causes perturbation of the HPA axis with impaired glucocorticoidnegative feedback (Jessop et al. 2001) and hypersecretion of cortisol in response to corticotropin-releasing factor (CRF) or stress (Mårin et al. 1992, Pasquali et al. 1993, Rosmond et al. 1998). Furthermore, cortisol directly impacts on metabolic function; however, this will not be addressed in the current review. Initial studies in rams show that high cortisol response to adrenocorticotropin (ACTH) is associated with lower feed-conversion efficiency (Knott et al. 2008). Furthermore, in rams, adiposity is correlated to cortisol responses to ACTH (Knott et al. 2008). More recent work shows that identification of high (HR) and low (LR) cortisol responders in female sheep can predict altered propensity to gain weight when exposed to a high-energy diet, where HR gain more adipose tissue than LR (Lee et al. $2014 b$ ). Thus, at least in female sheep, data suggest that 
cortisol responses can be used as a physiological marker that predicts propensity to become obese.

Previous studies in women suggest that HR eat more after a stressful episode than LR (Epel et al. 2001). Furthermore, HR individuals display preference for foods of high fat and sugar in response to psychological stress (Tomiyama et al. 2011). Similarly, in ewes, baseline food intake is similar in LR and HR, but HR eat more following either psychosocial (barking dog) or immune (lipopolysaccharide exposure) stressors (Lee et al. 2014c). In addition to altered food intake, HR ewes have reduced thermogenesis in skeletal muscle only; in response to meal feeding, post-prandial thermogenesis in skeletal muscle is greater in LR than in HR (Lee et al. $2014 b$ ). This again exemplifies divergence in the control of adipose tissue and skeletal muscle thermogenesis (Fig. 6).

Gene expression analyses reveal that LR and HR exhibit differences in 'set-point' in a number of hypothalamic systems. For example, at baseline in the non-stressed resting state, $\mathrm{HR}$ individuals show an overall upregulation of the HPA axis, with increased expression of CRF and arginine vasopressin, but reduced expression of oxytocin in the PVN (Hewagalamulage et al. 2016). In addition to altered expression of genes within the HPA axis, a key neuroendocrine feature of the LR and HR animals is altered expression of the MC3R and MC4R in the PVN (Fig. 6). Reduced $M C 4 R$ expression coincides with the development of melanocortin resistance. Central infusion of leptin reduces food intake in both LR and HR animals, but intracerebroventricular infusion of aMSH reduces food intake in LR only. Thus, reduced MC4R expression appears to be central to the metabolic phenotype of HR that confers increased propensity to become obese in HR individuals (Fig. 6). Interestingly, gene expression of $N P Y$, $A g R P$ and $P O M C$ in the arcuate nucleus is equivalent in LR and HR (Hewagalamulage et al. 2015). Hence, differences in the control of food intake and thermogenesis are most likely manifest at the level of the melanocortin receptor. Indeed, previous work in sheep has shown the MC4R to be central in mediating the reduction in food intake caused by immune challenge (Sartin et al. 2008). Furthermore, in rodents, direct injection of the melanocortin agonist melanotan II into the ventromedial nucleus of the hypothalamus increases skeletal muscle thermogenesis (Gavini et al. 2016). We propose that reduced expression of the $M C 4 R$ in HR animals underpins the metabolic phenotype wherein food intake is relatively increased in response to stress and reduced post-prandial thermogenesis in skeletal muscle is associated with propensity to become obese.

\section{Conclusion}

Historically, thermogenesis was considered to primarily occur in brown adipocytes and was solely driven by UCP1. It is now recognised that beige adipocytes and skeletal muscle also contribute to total thermogenic capacity and that thermogenesis is differentially regulated in these tissues. Indeed, in beige adipocytes, thermogenesis occurs via three distinct mechanisms, with these being UCP1-

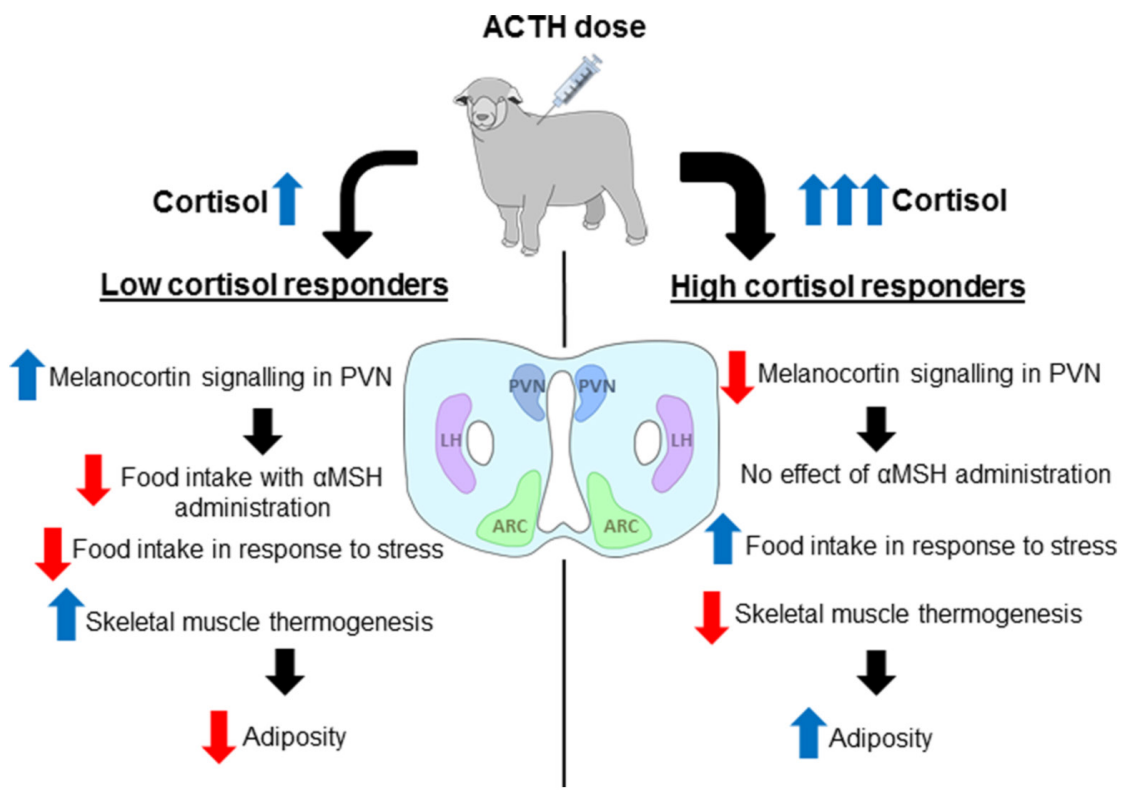

\section{Figure 6}

Schematic depiction of the altered metabolic phenotype in animals selected for either high or low cortisol responsiveness. Sheep are characterised as either high (HR) or low (LR) cortisol responders when given a standardised dose of adrenocorticotropic hormone. Animals characterized as HR have increased propensity to become obese, which is associated with perturbed control of food intake and reduced energy expenditure. Post-prandial thermogenesis in skeletal muscle is decreased in HR compared to LR ewes. Furthermore, food intake in response to stress is greater in HR than in LR and the former are resistant to the satiety effect of alphamelanocyte stimulating hormone (aMSH). High-cortisol-responding animals have reduced expression of the melanocortin 4 receptor (MC4R) in the paraventricular nucleus of the hypothalamus (PVN). We propose that the decreased levels of MC4R underpin the altered metabolic phenotype and increased propensity to become obese when compared to LR. 
driven mitochondrial uncoupling, futile creatine cycling and futile calcium cycling. On the other hand, in skeletal muscle, thermogenesis is associated with UCP3 and futile calcium cycling. Unlike rodents, large mammals including sheep and pigs do not contain a defined or circumscribed brown fat depot but have dispersed brown adipocytes within traditionally white fat depots. Large animals have provided invaluable insight into alternative mechanisms of thermogenesis. The sheep has been particularly useful in delineating the differential role of adipose tissue and skeletal muscle in the control of body weight. Furthermore, sheep models have allowed characterisation of the neuroendocrine pathways that may contribute to altered thermogenesis. We have shown that in sheep, both skeletal muscle and BAT differentially contribute to thermogenesis and therefore total energy expenditure. Changes in thermogenesis, however, do not exclusively associate with altered gene expression at the level of the arcuate nucleus. Indeed, decreased MC4R expression in HR animals and reduced orexin expression in the genetically obese animals coincide with altered thermogenic output. This review highlights the importance of the use of large animal models to ascertain the contribution and control of thermogenesis in multiple tissues and the relative role in the regulation of body weight.

\section{Declaration of interest}

The authors declare that there is no conflict of interest that could be perceived as prejudicing the impartiality of this review.

\section{Funding}

This work was supported by Australian Research Council grant number DP120103742 and National Health and Medical Research Council grant number APP1005935.

\section{Author contribution statement}

Both authors contributed equally to the writing and preparation of this review.

\section{References}

Afonso J \& Thompson JM 1996 Changes in body composition of sheep selected for high and low backfat thickness, during periods of ad libitum and maintenance feeding. Animal Science 63 395-406. (https://doi.org/10.1017/S1357729800015289)

Aherne W \& Hull D 1966 Brown adipose tissue and heat production in the newborn infant. Journal of Pathology and Bacteriology 91 223-234. (https://doi.org/10.1002/path.1700910126)
Alford S, Patel D, Perakakis N \& Mantzoros CS 2017 Obesity as a risk factor for Alzheimer's disease: weighing the evidence. Obesity Reviews 19 269-280. (https://doi.org/10.1111/obr.12629)

Alvarez-Crespo M, Csikasz RI, Martinez-Sanchez N, Dieguez C, Cannon B, Nedergaard J \& Lopez M 2016 Essential role of UCP1 modulating the central effects of thyroid hormones on energy balance. Molecular Metabolism 5 271-282. (https://doi.org/10.1016/j. molmet.2016.01.008)

Anukulkitch C, Rao A, Pereira A, McEwan J \& Clarke IJ 2010 Expression of genes for appetite-regulating peptides in the hypothalamus of genetically selected lean and fat sheep. Neuroendocrinology $\mathbf{9 1}$ 223-238. (https://doi.org/10.1159/000262283)

Arruda AP, Nigro M, Oliveira GM \& de Meis L 2007 Thermogenic activity of $\mathrm{Ca} 2+$-ATPase from skeletal muscle heavy sarcoplasmic reticulum: the role of ryanodine $\mathrm{Ca} 2+$ channel. Biochimica et Biophysica Acta 1768 1498-1505. (https://doi.org/10.1016/j. bbamem.2007.03.016)

Astrup A 1986 Thermogenesis in human brown adipose tissue and skeletal muscle induced by sympathomimetic stimulation. Acta Endocrinologica 112 (Supplement 278) S9-S32. (https://doi. org/10.1530/acta.0.112S009)

Astrup A, Bulow J, Madsen J \& Christensen NJ 1985 Contribution of BAT and skeletal muscle to thermogenesis induced by ephedrine in man. American Journal of Physiology 248 E507-E515. (https://doi. org/10.1152/ajpendo.2985.248.5.E507)

Bachman ES, Dhillon H, Zhang C-Y, Cinti S, Bianco AC, Kobilka BK \& Lowell BB 2002 beta AR signaling required for diet-induced thermogenesis and obesity resistance. Science 297 843-845. (https:// doi.org/10.1126/science.1073160)

Backholer K, Bowden M, Gamber K, Bjørbæk C, Iqbal J \& Clarke IJ 2010 Melanocortins mimic the effects of leptin to restore reproductive function in lean hypogonadotropic ewes. Neuroendocrinology 91 27-40. (https://doi.org/10.1159/000260060)

Bal NC, Maurya SK, Singh S, Wehrens XH \& Periasamy M 2016 Increased reliance on muscle-based thermogenesis upon acute minimization of brown adipose tissue function. Journal of Biological Chemistry 291 17247-17257. (https://doi.org/10.1074/jbc.M116.728188)

Bal NC, Maurya SK, Sopariwala DH, Sahoo SK, Gupta SC, Shaikh SA, Pant M, Rowland LA, Bombardier E, Goonasekera SA, et al. 2012 Sarcolipin is a newly identified regulator of muscle-based thermogenesis in mammals. Nature Medicine 18 1575-1579. (https:// doi.org/10.1038/nm.2897)

Balland E \& Cowley MA 2017 Short-term high-fat diet increases the presence of astrocytes in the hypothalamus of C57BL6 mice without altering leptin sensitivity. Journal of Neuroendocrinology 29 e12504. (https://doi.org/10.1111/jne.12504)

Balthasar N, Dalgaard LT, Lee CE, Yu J, Funahashi H, Williams T, Ferreira M, Tang V, McGovern RA, Kenny CD, et al. 2005 Divergence of melanocortin pathways in the control of food intake and energy expenditure. Cell 123 493-505. (https://doi.org/10.1016/j. cell.2005.08.035

Bamshad M, Song CK \& Bartness TJ 1999 CNS origins of the sympathetic nervous system outflow to brown adipose tissue. American Journal of Physiology 276 R1569-R1578.

Banks WA 2009 Characteristics of compounds that cross the blood-brain barrier. BMC Neurology 9 S3-S3. (https://doi.org/10.1186/1471-23779-S1-S3)

Barbatelli G, Murano I, Madsen L, Hao Q, Jimenez M, Kristiansen K, Giacobino JP, De Matteis R \& Cinti S 2010 The emergence of coldinduced brown adipocytes in mouse white fat depots is determined predominantly by white to brown adipocyte transdifferentiation. American Journal of Physiology: Endocrinology and Metabolism 298 E1244-E1253. (https://doi.org/10.1152/ajpendo.00600.2009)

Barrett P, Mercer JG \& Morgan PJ 2016 Preclinical models for obesity research. Disease Models and Mechanisms 9 1245-1255. (https://doi. org/10.1242/dmm.026443) 
Bauer PV, Hamr SC \& Duca FA 2016 Regulation of energy balance by a gut-brain axis and involvement of the gut microbiota. Cellular and Molecular Life Sciences 73 737-755. (https://doi.org/10.1007/s00018015-2083-z)

Berg F, Gustafson U \& Andersson L 2006 The uncoupling protein 1 Gene (UCP1) is disrupted in the pig lineage: a genetic explanation for poor thermoregulation in piglets. PLoS Genetics 2 e129. (https://doi. org/10.1371/journal.pgen.0020129)

Bertholet AM, Kazak L, Chouchani ET, Bogaczyńska MG, Paranjpe I, Wainwright GL, Bétourné A, Kajimura S, Spiegelman BM \& Kirichok Y 2017 Mitochondrial patch clamp of beige adipocytes reveals UCP1-positive and UCP1-negative cells both exhibiting futile creatine cycling. Cell Metabolism 25 811.e814-822.e814. (https://doi. org/10.1016/j.cmet.2017.03.002)

Bhaskaran K, Douglas I, Forbes H, dos-Santos-Silva I, Leon DA \& Smeeth L 2014 Body-mass index and risk of 22 specific cancers: a populationbased cohort study of 5.24 million UK adults. Lancet $\mathbf{3 8 4} 755-765$. (https://doi.org/10.1016/S0140-6736(14)60892-8)

Bhupathiraju SN \& Hu FB 2016 Epidemiology of obesity and diabetes and their cardiovascular complications. Circulation Research 118 1723-1735. (https://doi.org/10.1161/ CIRCRESAHA.115.306825)

Bi S, Robinson BM \& Moran TH 2003 Acute food deprivation and chronic food restriction differentially affect hypothalamic NPY mRNA expression. American Journal of Physiology: Regulatory, Integrative and Comparative Physiology 285 R1030-R1036. (https://doi.org/10.1152/ ajpregu.00734.2002)

Blaak EE, Saris WH \& van Baak MA 1993 Adrenoceptor subtypes mediating catecholamine-induced thermogenesis in man. International Journal of Obesity and Related Metabolic Disorders 17 (Supplement 3) S78-S81.

Blondin DP, Daoud A, Taylor T, Tingelstad HC, Bezaire V, Richard D, Carpentier AC, Taylor AW, Harper ME, Aguer C, et al. 2017 Four-week cold acclimation in adult humans shifts uncoupling thermogenesis from skeletal muscles to brown adipose tissue. Journal of Physiology 595 2099-2113. (https://doi.org/10.1113/ JP273395)

Blondin DP, Labbé SM, Phoenix S, Guérin B, Turcotte ÉE, Richard D, Carpentier AC \& Haman F 2015 Contributions of white and brown adipose tissues and skeletal muscles to acute cold-induced metabolic responses in healthy men. Journal of Physiology 593 701-714. (https:// doi.org/10.1113/jphysiol.2014.283598)

Bosy-Westphal A, Schautz B, Lagerpusch M, Pourhassan M, Braun W, Goele K, Heller M, Gluer CC \& Muller MJ 2013 Effect of weight loss and regain on adipose tissue distribution, composition of lean mass and resting energy expenditure in young overweight and obese adults. International Journal of Obesity 37 1371-1377. (https://doi org/10.1038/ijo.2013.1)

Broeders EP, Vijgen GH, Havekes B, Bouvy ND, Mottaghy FM, Kars M Schaper NC, Schrauwen P, Brans B \& van Marken Lichtenbelt WD 2016 Thyroid hormone activates brown adipose tissue and increases non-shivering thermogenesis - a cohort study in a group of thyroid carcinoma patients. PLOS ONE 11 e0145049. (https://doi.org/10.1371/ journal.pone.0145049)

Brunton PJ \& Russell JA 2011 Neuroendocrine control of maternal stress responses and fetal programming by stress in pregnancy. Progress in Neuro-Psychopharmacology and Biological Psychiatry 35 1178-1191. (https://doi.org/10.1016/j.pnpbp.2010.12.023)

Camps SG, Verhoef SP \& Westerterp KR 2015 Leptin and energy restriction induced adaptation in energy expenditure. Metabolism 64 1284-1290. (https://doi.org/10.1016/j.metabol.2015.06.016)

Cannon B \& Nedergaard J 2004 Brown adipose tissue: function and physiological significance. Physiology Reviews 84 277-359. (https://doi. org/10.1152/physrev.00015.2003)

Carey AL, Pajtak R, Formosa MF, Van Every B, Bertovic DA, Anderson MJ, Eikelis N, Lambert GW, Kalff V, Duffy SJ, et al. 2015 Chronic ephedrine administration decreases brown adipose tissue activity in a randomised controlled human trial: implications for obesity. Diabetologia 58 1045-1054. (https://doi.org/10.1007/s00125-0153543-6)

Carvalho SD, Kimura ET, Bianco AC \& Silva JE 1991 Central role of brown adipose tissue thyroxine 5 '-deiodinase on thyroid hormonedependent thermogenic response to cold. Endocrinology 128 2149-2159. (https://doi.org/10.1210/endo-128-4-2149)

Cinti S 2001 The adipose organ: morphological perspectives of adipose tissues. Proceedings of the Nutrition Society $60319-328$. (https://doi. org/10.1079/PNS200192)

Claret M, Smith MA, Batterham RL, Selman C, Choudhury AI, Fryer LG, Clements M, Al-Qassab H, Heffron H, Xu AW, et al. 2007 AMPK is essential for energy homeostasis regulation and glucose sensing by POMC and AgRP neurons. Journal of Clinical Investigation 117 2325-2336. (https://doi.org/10.1172/JCI31516)

Clarke SD, Lee K, Andrews ZB, Bischof R, Fahri F, Evans RG, Clarke IJ \& Henry BA 2012 Postprandial heat production in skeletal muscle is associated with altered mitochondrial function and altered futile calcium cycling. American Journal of Physiology: Regulatory, Integrative and Comparative Physiology 303 R1071-R1079. (https://doi. org/10.1152/ajpregu.00036.2012)

Clement K, Vaisse C, Lahlou N, Cabrol S, Pelloux V, Cassuto D, Gourmelen M, Dina C, Chambaz J, Lacorte JM, et al. 1998 A mutation in the human leptin receptor gene causes obesity and pituitary dysfunction. Nature 392 398-401. (https://doi.org/10.1038/32911)

Cockrem JF 2013 Individual variation in glucocorticoid stress responses in animals. General and Comparative Endocrinology 181 45-58. (https:// doi.org/10.1016/j.ygcen.2012.11.025)

Cohen P \& Spiegelman BM 2015 Brown and beige fat: molecular parts of a thermogenic machine. Diabetes 64 2346-2351. (https://doi. org/10.2337/db15-0318)

Coppola A, Liu Z, Andrews Z, Paradis E, Roy M-C, Friedman JM, Ricquier D, Richard D, Horvath TL, Gao X-B, et al. 2007 A central thermogenic-like mechanism in feeding regulation: an interplay between arcuate nucleus T3 and UCP2. Cell Metabolism 5 21-33. (https://doi.org/10.1016/j.cmet.2006.12.002)

Cousin B, Cinti S, Morroni M, Raimbault S, Ricquier D, Penicaud L \& Casteilla L 1992 Occurrence of brown adipocytes in rat white adipose tissue: molecular and morphological characterization. Journal of Cell Science 103 931-942.

Cowley MA, Pronchuk N, Fan W, Dinulescu DM, Colmers WF \& Cone RD 1999 Integration of NPY, AGRP, and melanocortin signals in the hypothalamic paraventricular nucleus: evidence of a cellular basis for the adipostat. Neuron 24 155-163. (https://doi.org/10.1016/S08966273(00)80829-6)

Cowley MA, Smart JL, Rubinstein M, Cerdan MG, Diano S, Horvath TL, Cone RD \& Low MJ 2001 Leptin activates anorexigenic POMC neurons through a neural network in the arcuate nucleus. Nature $\mathbf{4 1 1}$ 480-484. (https://doi.org/10.1038/35078085)

Cunningham S, Leslie P, Hopwood D, Illingworth P, Jung RT, Nicholls DG, Peden N, Rafael J \& Rial E 1985 The characterization and energetic potential of brown adipose tissue in man. Clinical Science 69 343-348. (https://doi.org/10.1042/cs0690343)

Cypess AM, Lehman S, Williams G, Tal I, Rodman D, Goldfine AB, Kuo FC, Palmer EL, Tseng Y-H, Doria A, et al. 2009 Identification and importance of brown adipose tissue in adult humans. New England Journal of Medicine 360 1509-1517. (https://doi.org/10.1056/ NEJMoa0810780)

Cypess AM, Weiner LS, Roberts-Toler C, Elia EF, Kessler SH, Kahn PA, English J, Chatman K, Trauger SA, Doria A, et al. 2015 Activation of human brown adipose tissue by a beta3-adrenergic receptor agonist. Cell Metabolism 21 33-38. (https://doi.org/10.1016/j. cmet.2014.12.009)

Cypess AM, White AP, Vernochet C, Schulz TJ, Xue R, Sass CA, Huang TL, Roberts-Toler C, Weiner LS \& Sze C 2013 Anatomical localization, 
gene expression profiling and functional characterization of adult human neck brown fat. Nature Medicine 19 635-639. (https://doi. org/10.1038/nm.3112)

Dalgaard K, Landgraf K, Heyne S, Lempradl A, Longinotto J, Gossens K, Ruf M, Orthofer M, Strogantsev R, Selvaraj M, et al. 2016 Trim28 haploinsufficiency triggers bi-stable epigenetic obesity. Cell 164 353-364. (https://doi.org/10.1016/j.cell.2015.12.025)

de Meis L, Arruda AP \& Carvalho DP 2005 Role of sarco/endoplasmic reticulum $\mathrm{Ca}(2+)$-ATPase in thermogenesis. Bioscience Reports $\mathbf{2 5}$ 181-190. (https://doi.org/10.1007/s10540-005-2884-7)

Elias CF, Aschkenasi C, Lee C, Kelly J, Ahima RS, Bjorbaek C, Flier JS, Saper CB \& Elmquist JK 1999 Leptin differentially regulates NPY and POMC neurons projecting to the lateral hypothalamic area. Neuron $\mathbf{2 3}$ 775-786. (https://doi.org/10.1016/S0896-6273(01)80035-0)

Epel E, Lapidus R, McEwen B \& Brownell K 2001 Stress may add bite to appetite in women: a laboratory study of stress-induced cortisol and eating behavior. Psychoneuroendocrinology 26 37-49. (https://doi. org/10.1016/S0306-4530(00)00035-4)

Farooqi IS 2008 Monogenic human obesity. Frontiers of Hormone Research 36 1-11. (https://doi.org/10.1159/0000115333)

Farooqi IS, Keogh JM, Yeo GS, Lank EJ, Cheetham T \& O’Rahilly S 2003 Clinical spectrum of obesity and mutations in the melanocortin 4 receptor gene. New England Journal of Medicine 348 1085-1095. (https://doi.org/10.1056/NEJMoa022050)

Francis SM, Veenvliet BA, Stuart SK, Littlejohn RP \& Suttie JM 1998 Growth hormone secretion and pituitary gland weight in suckling lambs from genetically lean and fat sheep. New Zealand Journal of Agricultural Research 41 387-393. (https://doi.org/10.1080/00288233. 1998.9513323)

Francis SM, Venters SJ, Duxson MJ \& Suttie JM 2000 Differences in pituitary cell number but not cell type between genetically lean and fat Coopworth sheep. Domestic Animal Endocrinology 18 229-239. (https://doi.org/10.1016/S0739-7240(99)00081-8)

French MC, Littlejohn RP, Greer GJ, Bain WE, McEwan JC \& Tisdall DJ 2006 Growth hormone and ghrelin receptor genes are differentially expressed between genetically lean and fat selection lines of sheep. Journal of Animal Science 84 324-331. (https://doi. org/10.2527/2006.842324x)

Fromme T, Hoffmann C, Nau K, Rozman J, Reichwald K, Utting M, Platzer M \& Klingenspor M 2009 An intronic single base exchange leads to a brown adipose tissue-specific loss of UCP3 expression and an altered body mass trajectory. American Journal of Physiology: Physiological Genomics 38 54-62. (https://doi.org/10.1152/ physiolgenomics.00249.2007)

Fuster JJ, Ouchi N, Gokce N \& Walsh K 2016 Obesity-induced changes in adipose tissue microenvironment and their impact on cardiovascular disease. Circulation Research 118 1786-1807. (https://doi.org/10.1161/ CIRCRESAHA.115.306885)

Gaborit B, Venteclef N, Ancel P, Pelloux V, Gariboldi V, Leprince P, Amour J, Hatem SN, Jouve E, Dutour A, et al. 2015 Human epicardial adipose tissue has a specific transcriptomic signature depending on its anatomical peri-atrial, peri-ventricular, or peri-coronary location. Cardiovascular Research 108 62-73. (https://doi.org/10.1093/cvr/ crv208)

Garg SK, Maurer H, Reed K \& Selagamsetty R 2014 Diabetes and cancer: two diseases with obesity as a common risk factor. Diabetes, Obesity and Metabolism 16 97-110.

Gavini CK, Jones WC 2nd \& Novak CM 2016 Ventromedial hypothalamic melanocortin receptor activation: Regulation of activity energy expenditure and skeletal muscle thermogenesis. Journal of Physiology 594 5285-5301. (https://doi.org/10.1113/ JP272352)

Gong DW, He Y, Karas M \& Reitman M 1997 Uncoupling protein-3 is a mediator of thermogenesis regulated by thyroid hormone, beta3adrenergic agonists, and leptin. Journal of Biological Chemistry 272 24129-24132. (https://doi.org/10.1074/jbc.272.39.24129)
Hara J, Beuckmann CT, Nambu T, Willie JT, Chemelli RM, Sinton CM, Sugiyama F, Yagami K, Goto K, Yanagisawa M, et al. 2001 Genetic ablation of orexin neurons in mice results in narcolepsy, hypophagia, and obesity. Neuron 30 345-354. (https://doi.org/10.1016/S08966273(01)00293-8)

Harms M \& Seale P 2013 Brown and beige fat: development, function and therapeutic potential. Nature Medicine 19 1252-1263. (https://doi. org/10.1038/nm.3361)

Heaton JM 1972 The distribution of brown adipose tissue in the human. Journal of Anatomy 112 35-39.

Henry BA, Dunshea FR, Gould M \& Clarke IJ 2008 Profiling postprandial thermogenesis in muscle and fat of sheep and the central effect of leptin administration. Endocrinology 149 2019-2026. (https://doi org/10.1210/en.2007-1311)

Henry BA, Loughnan R, Hickford J, Young IR, St John J \& Clarke IJ 2015 Differences in mitochondrial DNA inheritance and function align with body conformation in genetically lean and fat sheep. Journal of Animal Science 93 2083-2093. (https://doi.org/10.2527/jas.2014-8764)

Henry BA, Pope M, Birtwistle M, Loughnan R, Alagal R, Fuller-Jackson JP, Perry V, Budge H, Clarke IJ \& Symonds ME 2017 Ontogeny and thermogenic role for sternal fat in female sheep. Endocrinology $\mathbf{1 5 8}$ 2212-2225. (https://doi.org/10.1210/en.2017-00081)

Henry BA, Tilbrook AJ, Dunshea FR, Rao A, Blache D, Martin GB \& Clarke IJ 2000 Long-term alterations in adiposity affect the expression of melanin-concentrating hormone and enkephalin but not proopiomelanocortin in the hypothalamus of ovariectomized ewes. Endocrinology 141 1506-1514. (https://doi.org/10.1210/ endo.141.4.7434)

Hermann DM, Luppi PH, Peyron C, Hinckel P \& Jouvet M 1997 Afferent projections to the rat nuclei raphe magnus, raphe pallidus and reticularis gigantocellularis pars alpha demonstrated by iontophoretic application of choleratoxin (subunit b). Journal of Chemical Neuroanatomy 13 1-21. (https://doi.org/10.1016/S08910618(97)00019-7)

Hewagalamulage SD, Clarke IJ, Rao A \& Henry BA 2016 Ewes with divergent cortisol responses to adrenocorticotropin (ACTH) exhibit functional differences in the hypothalamo-pituitary-adrenal (HPA) axis. Endocrinology 157 3540-3549. (https://doi.org/10.1210/en.20161287)

Hewagalamulage SD, Clarke IJ, Young IR, Rao A \& Henry BA 2015 High cortisol response to adrenocorticotrophic hormone identifies ewes with reduced melanocortin signalling and increased propensity to obesity. Neuroendocrinology 27 44-56. (https://doi.org/10.1111/ jne.12233)

Hillman JB, Dorn LD \& Bin H 2010 Association of anxiety and depressive symptoms and adiposity among adolescent females, using dual energy X-ray absorptiometry. Clinical Pediatrics 49 671-677. (https:// doi.org/10.1177/0009922810363155)

Himms-Hagen J, Melnyk A, Zingaretti MC, Ceresi E, Barbatelli G \& Cinti S 2000 Multilocular fat cells in WAT of CL-316243-treated rats derive directly from white adipocytes. American Journal of Physiology: Cell Physiology 279 C670. (https://doi.org/10.1152/ ajpcell.2000.279.3.C670)

Hou L, Shi J, Cao L, Xu G, Hu C \& Wang C 2017 Pig has no uncoupling protein 1. Biochemical and Biophysical Research Communications $\mathbf{4 8 7}$ 795-800. (https://doi.org/10.1016/j.bbrc.2017.04.118)

Ikeda K, Kang Q, Yoneshiro T, Camporez JP, Maki H, Homma M, Shinoda K, Chen Y, Lu X, Maretich P, et al. 2017 UCP1-independent signaling involving SERCA2b-mediated calcium cycling regulates beige fat thermogenesis and systemic glucose homeostasis. Nature Medicine 23 1454-1465 (https://doi.org/10.1038/nm.4429)

Iqbal J, Henry BA, Pompolo S, Rao A \& Clarke IJ 2003 Long-term alteration in bodyweight and food restriction does not affect the gene expression of either preproorexin or prodynorphin in the sheep. Neuroscience 118 217-226. (https://doi.org/10.1016/S03064522(02)00815-1) 
Iqbal J, Pompolo S, Dumont LM, Wu CS, Mountjoy KG, Henry BA \& Clarke IJ 2001 Long-term alterations in body weight do not affect the expression of melanocortin receptor-3 and -4 mRNA in the ovine hypothalamus. Neuroscience 105 931-940. (https://doi.org/10.1016/ S0306-4522(01)00250-0)

Ito M, Gomori A, Ishihara A, Oda Z, Mashiko S, Matsushita H, Yumoto M, Ito M, Sano H, Tokita S, et al. 2003 Characterization of $\mathrm{MCH}$ mediated obesity in mice. American Journal of Physiology: Endocrinology and Metabolism 284 E940-E945. (https://doi.org/10.1152/ ajpendo.00529.2002)

Jackson RS, Creemers JWM, Ohagi S, Raffin-Sanson M-L, Sanders L, Montague CT, Hutton JC \& O'Rahilly S 1997 Obesity and impaired prohormone processing associated with mutations in the human prohormone convertase 1 gene. Nature Genetics 16 303. (https://doi. org/10.1038/ng0797-303)

Jankovic A, Golic I, Markelic M, Stancic A, Otasevic V, Buzadzic B, Korac A \& Korac B 2015 Two key temporally distinguishable molecular and cellular components of white adipose tissue browning during cold acclimation. Journal of Physiology 593 3267-3280. (https://doi.org/10.1113/JP270805)

Jespersen NZ, Larsen TJ, Peijs L, Daugaard S, Homoe P, Loft A, de Jong J, Mathur N, Cannon B, Nedergaard J, et al. 2013 A classical brown adipose tissue mRNA signature partly overlaps with brite in the supraclavicular region of adult humans. Cell Metabolism 17 798-805. (https://doi.org/10.1016/j.cmet.2013.04.011)

Jessop DS, Dallman MF, Fleming D \& Lightman SL 2001 Resistance to glucocorticoid feedback in obesity. Journal of Clinical Endocrinology and Metabolism 86 4109-4114. (https://doi.org/10.1210/ jcem.86.9.7826)

Johnston CS, Day CS \& Swan PD 2002 Postprandial thermogenesis Is increased $100 \%$ on a high-protein, low-fat diet versus a highcarbohydrate, low-fat diet in healthy, young women. Journal of the American College of Nutrition 21 55-61. (https://doi.org/10.1080/07315 724.2002.10719194)

Kamegai J, Tamura H, Shimizu T, Ishii S, Sugihara H \& Wakabayashi I 2001 Chronic central infusion of ghrelin increases hypothalamic neuropeptide $\mathrm{Y}$ and Agouti-related protein mRNA levels and body weight in rats. Diabetes 50 2438-2443. (https://doi.org/10.2337/ diabetes.50.11.2438)

Kask A, Rago L \& Harro J 1998 Evidence for involvement of neuropeptide $\mathrm{Y}$ receptors in the regulation of food intake: studies with Y1-selective antagonist BIBP3226. British Journal of Pharmacology 124 1507-1515. (https://doi.org/10.1038/sj.bjp.0701969)

Kazak L, Chouchani Edward T, Jedrychowski Mark P, Erickson Brian K, Shinoda K, Cohen P, Vetrivelan R, Lu Gina Z, Laznik-Bogoslavski D, Hasenfuss Sebastian C, et al. 2015 A creatine-driven substrate cycle enhances energy expenditure and thermogenesis in beige fat. Cell 163 643-655. (https://doi.org/10.1016/j.cell.2015.09.035)

Kirchner H, Heppner KM \& Tschop MH 2012 The role of ghrelin in the control of energy balance. Handbook of Experimental Pharmacology 209 161-184. (https://doi.org/10.1007/978-3-642-24716-3_7)

Knott SA, Cummins LJ, Dunshea FR \& Leury BJ 2008 Rams with poor feed efficiency are highly responsive to an exogenous adrenocorticotropin hormone (ACTH) challenge. Domestic Animal Endocrinology 34 261-268. (https://doi.org/10.1016/j.domaniend.2007.07.002)

Krude H, Biebermann H, Luck W, Horn R, Brabant G \& Gruters A 1998 Severe early-onset obesity, adrenal insufficiency and red hair pigmentation caused by POMC mutations in humans. Nature Genetics 19 155-157. (https://doi.org/10.1038/509)

Lee P, Werner CD, Kebebew E \& Celi FS 2014a Functional thermogenic beige adipogenesis is inducible in human neck fat. International Journal of Obesity 38 170-176. (https://doi.org/10.1038/ijo.2013.82)

Lee TK, Clarke IJ, St John J, Young IR, Leury BL, Rao A, Andrews ZB \& Henry BA $2014 b$ High cortisol responses identify propensity for obesity that is linked to thermogenesis in skeletal muscle. FASEB Journal 28 35-44. (https://doi.org/10.1096/fj.13-238345)
Lee TK, Lee C, Bischof R, Lambert GW, Clarke IJ \& Henry BA 2014c Stress-induced behavioral and metabolic adaptations lead to an obesity-prone phenotype in ewes with elevated cortisol responses. Psychoneuroendocrinology 47 166-177. (https://doi.org/10.1016/j. psyneuen.2014.05.015)

Leibel RL, Rosenbaum M \& Hirsch J 1995 Changes in energy expenditure eesulting from altered body weight. New England Journal of Medicine 332 621-628. (https://doi.org/10.1056/ NEJM199503093321001)

LeRoith D, Novosyadlyy R, Gallagher EJ, Lann D, Vijayakumar A \& Yakar S 2008 Obesity and type 2 diabetes are associated with an increased risk of developing cancer and a worse prognosis; epidemiological and mechanistic evidence. Experimental and Clinical Endocrinology and Diabetes 116 (Supplement 1) S4-S6. (https://doi. org/10.1055/s-2008-1081488)

Lewis DE, Shellard L, Koeslag DG, Boer DE, McCarthy HD, McKibbin PE, Russell JC \& Williams G 1993 Intense exercise and food restriction cause similar hypothalamic neuropeptide Y increases in rats. American Journal of Physiology 264 E279-E284. (https://doi.org/10.1152/ ajpendo.1993.264.2.E279)

Lillycrop KA \& Burdge GC 2010 Epigenetic changes in early life and future risk of obesity. International Journal of Obesity 35 72. (https:// doi.org/10.1038/ijo.2010.122)

Lin J, Cao C, Tao C, Ye R, Dong M, Zheng Q, Wang C, Jiang X, Qin G, Yan C, et al. 2017 Cold adaptation in pigs depends on UCP3 in beige adipocytes. Journal of Molecular Cell Biology 9 364-375. (https://doi. org/10.1093/jmcb/mjx018)

Locke AE, Kahali B, Berndt SI, Justice AE, Pers TH, Day FR, Powell C, Vedantam S, Buchkovich ML, Yang J, et al. 2015 Genetic studies of body mass index yield new insights for obesity biology. Nature $\mathbf{5 1 8}$ 197-206. (https://doi.org/10.1038/nature14177)

Lopez M, Varela L, Vazquez MJ, Rodriguez-Cuenca S, Gonzalez CR, Velagapudi VR, Morgan DA, Schoenmakers E, Agassandian K, Lage R, et al. 2010 Hypothalamic AMPK and fatty acid metabolism mediate thyroid regulation of energy balance. Nature Medicine 16 1001-1008. (https://doi.org/10.1038/nm.2207)

Lowell BB \& Spiegelman BM 2000 Towards a molecular understanding of adaptive thermogenesis. Nature $\mathbf{4 0 4}$ 652-660. (https://doi. org/10.1038/35007527)

Luquet S, Perez FA, Hnasko TS \& Palmiter RD 2005 NPY/AgRP neurons are essential for feeding in adult mice but can be ablated in neonates. Science $\mathbf{3 1 0}$ 683-685. (https://doi.org/10.1126/ science.1115524)

Lutz TA \& Woods SC 2012 Overview of animal models of obesity. In Current Protocols in Pharmacology, chapter 5, unit 5.61. Hoboken, NJ, USA: Wiley. (https://doi.org/10.1002/0471141755.ph0561s58)

Mårin P, Darin N, Amemiya T, Andersson B, Jern S \& Björntorp P 1992 Cortisol secretion in relation to body fat distribution in obese premenopausal women. Metabolism 41 882-886.

Matthias A, Ohlson KB, Fredriksson JM, Jacobsson A, Nedergaard J \& Cannon B 2000 Thermogenic responses in brown fat cells are fully UCP1-dependent. UCP2 or UCP3 do not substitute for UCP1 in adrenergically or fatty acid-induced thermogenesis. Journal of Biological Chemistry 275 25073-25081. (https://doi.org/10.1074/jbc. M000547200)

Maurya SK, Bal NC, Sopariwala DH, Pant M, Rowland LA, Shaikh SA \& Periasamy M 2015 Sarcolipin is a key determinant of the basal metabolic rate, and its overexpression enhances energy expenditure and resistance against diet-induced obesity. Journal of Biological Chemistry 290 10840-10849. (https://doi.org/10.1074/jbc. M115.636878)

McShane TM, Petersen SL, McCrone S \& Keisler DH 1993 Influence of food restriction on neuropeptide-Y, proopiomelanocortin, and luteinizing hormone-releasing hormone gene expression in sheep hypothalami. Biology of Reproduction 49 831-839. (https://doi. org/10.1095/biolreprod49.4.831)
(C) 2018 Society for Endocrinology Published by Bioscientifica Ltd. Printed in Great Britain 
Mohammed M, Yanagisawa M, Blessing W \& Ootsuka Y 2016 Attenuated cold defense responses in orexin neuron-ablated rats. Temperature $\mathbf{3}$ 465-475. (https://doi.org/10.1080/23328940.2016.1184366)

Montague CT, Farooqi IS, Whitehead JP, Soos MA, Rau H, Wareham NJ, Sewter CP, Digby JE, Mohammed SN, Hurst JA, et al. 1997 Congenital leptin deficiency is associated with severe early-onset obesity in humans. Nature 387 903-908. (https://doi.org/10.1038/43185)

Morris CA, McEwan JC, Fennessy PF, Bain WE, Greer GJ \& Hickey SM 1997 Selection for high or low backfat depth in Coopworth sheep: juvenile traits. Animal Science 65 93-103. (https://doi.org/10.1017/ S1357729800016349)

Morrison SF 2016 Central neural control of thermoregulation and brown adipose tissue. Autonomic Neuroscience: Basic and Clinical 196 14-24. (https://doi.org/10.1016/j.autneu.2016.02.010)

Morroni M, Barbatelli G, Zingaretti MC \& Cinti S 1995 Immunohistochemical, ultrastructural and morphometric evidence for brown adipose tissue recruitment due to cold acclimation in old rats. International Journal of Obesity and Related Metabolic Disorders 19 126-131.

Mountjoy KG 2010 Functions for pro-opiomelanocortin-derived peptides in obesity and diabetes. Biochemical Journal 428 305-324. (https://doi org/10.1042/BJ20091957)

Nakamura K \& Morrison SF 2007 Central efferent pathways mediating skin cooling-evoked sympathetic thermogenesis in brown adipose tissue. American Journal of Physiology: Regulatory, Integrative and Comparative Physiology 292 R127-R136. (https://doi.org/10.1152/ ajpregu.00427.2006)

Nedergaard J, Bengtsson T \& Cannon B 2007 Unexpected evidence for active brown adipose tissue in adult humans. American Journal of Physiology: Endocrinology and Metabolism 293 E444-E452. (https://doi. org/10.1152/ajpendo.00691.2006)

Nedergaard J \& Cannon B 2013 How brown is brown fat? It depends where you look. Nature Medicine 19 540-541. (https://doi. org/10.1038/nm.3187)

Newman E, O'Connor DB \& Conner M 2007 Daily hassles and eating behaviour: the role of cortisol reactivity status. Psychoneuroendocrinology 32 125-132. (https://doi.org/10.1016/j. psyneuen.2006.11.006)

Nijenhuis WA, Oosterom J \& Adan RA 2001 AgRP(83-132) acts as an inverse agonist on the human-melanocortin-4 receptor. Molecular Endocrinology 15 164-171. (https://doi.org/10.1210/ mend.15.1.0578)

Oldfield BJ, Giles ME, Watson A, Anderson C, Colvill LM \& McKinley MJ 2002 The neurochemical characterisation of hypothalamic pathways projecting polysynaptically to brown adipose tissue in the rat. Neuroscience 110 515-526. (https://doi.org/10.1016/S03064522(01)00555-3)

Ortega FB, Lavie CJ \& Blair SN 2016 Obesity and cardiovascular disease. Circulation Research 118 1752-1770. (https://doi.org/10.1161/ CIRCRESAHA.115.306883)

Park H-K \& Ahima RS 2015 Physiology of leptin: energy homeostasis, neuroendocrine function and metabolism. Metabolism: Clinical and Experimental 64 24-34. (https://doi.org/10.1016/j. metabol.2014.08.004)

Pasquali R, Cantobelli S, Casimirri F, Capelli M, Bortoluzzi L, Flamia R, Labate AM \& Barbara L 1993 The hypothalamic-pituitary-adrenal axis in obese women with different patterns of body fat distribution. Journal of Clinical Endocrinology and Metabolism 77 341-346. (https:// doi.org/10.1210/jcem.77.2.8393881)

Perusse L, Rankinen T, Zuberi A, Chagnon YC, Weisnagel SJ, Argyropoulos G, Walts B, Snyder EE \& Bouchard C 2005 The human obesity gene map: the 2004 update. Obesity Research 13 381-490. (https://doi.org/10.1038/oby.2005.50)

Pope M, Budge H \& Symonds ME 2014 The developmental transition of ovine adipose tissue through early life. Acta Physiologica 210 20-30. (https://doi.org/10.1111/apha.12053)
Ravussin E, Lillioja S, Knowler WC, Christin L, Freymond D, Abbott WG, Boyce V, Howard BV \& Bogardus C 1988 Reduced rate of energy expenditure as a risk factor for body-weight gain. New England Journal of Medicine 318 467-472. (https://doi.org/10.1056/ NEJM198802253180802)

Rogers NH, Walsh H, Alvarez-Garcia O, Park S, Gaylinn B, Thorner MO \& Smith RG 2016 Metabolic benefit of chronic caloric restriction and activation of hypothalamic AGRP/NPY neurons in male mice Is independent of ghrelin. Endocrinology 157 1430-1442. (https://doi. org/10.1210/en.2015-1745)

Rosenbaum M, Hirsch J, Gallagher DA \& Leibel RL 2008 Long-term persistence of adaptive thermogenesis in subjects who have maintained a reduced body weight. American Journal of Clinical Nutrition 88 906-912. (https://doi.org/10.1093/ajcn/88.4.906)

Rosenwald M, Perdikari A, Rulicke T \& Wolfrum C 2013 Bi-directional interconversion of brite and white adipocytes. Nature Cell Biology $\mathbf{1 5}$ 659-667. (https://doi.org/10.1038/ncb2740)

Rosmond R, Dallman MF \& Bjorntorp P 1998 Stress-related cortisol secretion in men: relationships with abdominal obesity and endocrine, metabolic and hemodynamic abnormalities. Journal of Clinical Endocrinology and Metabolism 83 1853-1859. (https://doi. org/10.1210/jcem.83.6.4843)

Rowlatt U, Mrosovsky N \& English A 1971 A comparative survey of brown fat in the neck and axilla of mammals at birth. Neonatology $\mathbf{1 7}$ 53-83. (https://doi.org/10.1159/000240303)

Ryu V, Garretson JT, Liu Y, Vaughan CH \& Bartness TJ 2015 Brown adipose tissue has sympathetic-sensory feedback circuits. Journal of Neuroscience 35 2181-2190. (https://doi.org/10.1523/ JNEUROSCI.3306-14.2015)

Saito M, Okamatsu-Ogura Y, Matsushita M, Watanabe K, Yoneshiro T, Nio-Kobayashi J, Iwanaga T, Miyagawa M, Kameya T, Nakada K, et al. 2009 High incidence of metabolically active brown adipose tissue in healthy adult humans: effects of cold exposure and adiposity. Diabetes 58 1526-1531. (https://doi.org/10.2337/db09-0530)

Sanchez-Gurmaches J, Hung C-M, Sparks CA, Tang Y, Li H \& Guertin DA 2012 PTEN loss in the Myf5 lineage redistributes body fat and reveals subsets of white adipocytes that arise from Myf5 precursors. Cell Metabolism 16 348-362. (https://doi.org/10.1016/j.cmet.2012.08.003)

Sapolsky RM, Krey LC \& McEwen BS $1986 a$ The adrenocortical axis in the aged rat: impaired sensitivity to both fast and delayed feedback inhibition. Neurobiology of Aging 7 331-335. (https://doi. org/10.1016/0197-4580(86)90159-4)

Sapolsky RM, Krey LC \& McEwen BS $1986 b$ The neuroendocrinology of stress and aging: the glucocorticoid cascade hypothesis. Endocrine Reviews 7 284-301. (https://doi.org/10.1210/edrv-7-3-284)

Sartin JL, Marks DL, McMahon CD, Daniel JA, Levasseur P, Wagner CG, Whitlock BK \& Steele BP 2008 Central role of the melanocortin-4 receptors in appetite regulation after endotoxin. Journal of Animal Science 86 2557-2567. (https://doi.org/10.2527/jas.2008-0916)

Sbarbati A, Morroni M, Zancanaro C \& Cinti S 1991 Rat interscapular brown adipose tissue at different ages: a morphometric study. International Journal of Obesity 15 581-587.

Seale P, Bjork B, Yang W, Kajimura S, Chin S, Kuang S, Scime A, Devarakonda S, Conroe HM, Erdjument-Bromage H, et al. 2008 PRDM16 controls a brown fat/skeletal muscle switch. Nature $\mathbf{4 5 4}$ 961-967. (https://doi.org/10.1038/nature07182)

Segal-Lieberman G, Bradley RL, Kokkotou E, Carlson M, Trombly DJ, Wang X, Bates S, Myers MG Jr, Flier JS \& Maratos-Flier E 2003 Melanin-concentrating hormone is a critical mediator of the leptin-deficient phenotype. PNAS 100 10085-10090. (https://doi org/10.1073/pnas.1633636100)

Sellayah D, Bharaj P \& Sikder D 2011 Orexin is required for brown adipose tissue development, differentiation, and function. Cell Metabolism 14 478-490. (https://doi.org/10.1016/j.cmet.2011.08.010)

Shabalina IG, Petrovic N, de Jong JM, Kalinovich AV, Cannon B \& Nedergaard J 2013 UCP1 in brite/beige adipose tissue mitochondria http://joe.endocrinology-journals.org

https://doi.org/10.1530/JOE-18-0090 (c) 2018 Society for Endocrinology Published by Bioscientifica Ltd. Printed in Great Britain 
is functionally thermogenic. Cell Reports 5 1196-1203. (https://doi. org/10.1016/j.celrep.2013.10.044)

Sharp LZ, Shinoda K, Ohno H, Scheel DW, Tomoda E, Ruiz L, Hu H, Wang L, Pavlova Z, Gilsanz V, et al. 2012 Human BAT possesses molecular signatures that resemble beige/brite cells. PLOS ONE 7 e49452. (https://doi.org/10.1371/journal.pone.0049452)

Shimada M, Tritos NA, Lowell BB, Flier JS \& Maratos-Flier E 1998 Mice lacking melanin-concentrating hormone are hypophagic and lean. Nature 396 670-674. (https://doi.org/10.1038/25341)

Simonides WS, Thelen MH, van der Linden CG, Muller A \& van Hardeveld C 2001 Mechanism of thyroid-hormone regulated expression of the SERCA genes in skeletal muscle: implications for thermogenesis. Bioscience Reports 21 139-154. (https://doi. org/10.1023/A:1013692023449)

Song CK, Schwartz GJ \& Bartness TJ 2009 Anterograde transneuronal viral tract tracing reveals central sensory circuits from white adipose tissue. American Journal of Physiology: Regulatory, Integrative and Comparative Physiology 296 R501-R511. (https://doi.org/10.1152/ ajpregu.90786.2008)

Stob NR, Bell C, van Baak MA \& Seals DR 2007 Thermic effect of food and beta-adrenergic thermogenic responsiveness in habitually exercising and sedentary healthy adult humans. Journal of Applied Physiology 103 616-622. (https://doi.org/10.1152/japplphysiol.01434.2006)

Stunkard A \& McLaren-Hume M 1959 The results of treatment for obesity: a review of the literature and report of a series. A.M.A. Archives of Internal Medicine 103 79-85.

Sugino T, Yamaura J, Yamagishi M, Ogura A, Hayashi R, Kurose Y, Kojima M, Kangawa K, Hasegawa Y \& Terashima Y 2002 A transient surge of ghrelin secretion before feeding is modified by different feeding regimens in sheep. Biochemical and Biophysical Research Communications 298 785-788. (https://doi.org/10.1016/S0006291X(02)02572-X)

Sumithran P, Prendergast LA, Delbridge E, Purcell K, Shulkes A, Kriketos A \& Proietto J 2011 Long-term persistence of hormonal adaptations to weight loss. New England Journal of Medicine 365 1597-1604. (https:// doi.org/10.1056/NEJMoa1105816)

Symonds ME 2013 Brown adipose tissue growth and development. Scientifica 2013 14. (https://doi.org/10.1155/2013/305763)

Symonds ME, Pope M, Sharkey D \& Budge H 2012 Adipose tissue and fetal programming. Diabetologia 55 1597-1606. (https://doi. org/10.1007/s00125-012-2505-5)

Takahashi T, Kobayashi Y, Hasegawa S, Touno E, Otani Y, Haga S, Itoh F, Katoh K \& Obara Y 2008 Different responses in postprandial plasma ghrelin and GH levels induced by concentrate or timothy hay feeding in wethers. Domestic Animal Endocrinology 34 432-439. (https://doi. org/10.1016/j.domaniend.2007.12.003)

Teske JA, Billington CJ \& Kotz CM 2008 Neuropeptidergic mediators of spontaneous physical activity and non-exercise activity thermogenesis. Neuroendocrinology 87 71-90. (https://doi. org $/ 10.1159 / 000110802)$

Tilbrook AJ \& Clarke IJ 2006 Neuroendocrine mechanisms of innate states of attenuated responsiveness of the hypothalamo-pituitary adrenal axis to stress. Frontiers in Neuroendocrinology 27 285-307. (https://doi.org/10.1016/j.yfrne.2006.06.002)

Tomiyama AJ, Dallman MF \& Epel ES 2011 Comfort food is comforting to those most stressed: evidence of the chronic stress response network in high stress women. Psychoneuroendocrinology 36 1513-1519. (https://doi.org/10.1016/j.psyneuen.2011.04.005)

Touma C, Bunck M, Glasl L, Nussbaumer M, Palme R, Stein H, Wolferstatter M, Zeh R, Zimbelmann M, Holsboer F, et al. 2008 Mice selected for high versus low stress reactivity: a new animal model for affective disorders. Psychoneuroendocrinology 33 839-862. (https://doi. org/10.1016/j.psyneuen.2008.03.013)

Trayhurn P, Temple NJ \& Van Aerde J 1989 Evidence from immunoblotting studies on uncoupling protein that brown adipose tissue is not present in the domestic pig. Canadian Journal of
Physiology and Pharmacology 67 1480-1485. (https://doi.org/10.1139/ y89-239)

Tremmel M, Gerdtham U-G, Nilsson P \& Saha S 2017 Economic burden of obesity: a systematic literature review. International Journal of Environmental Research and Public Health 14 435. (https://doi. org/10.3390/ijerph14040435)

Turner AI, Canny BJ, Hobbs RJ, Bond JD, Clarke IJ \& Tilbrook AJ 2002 Influence of sex and gonadal status of sheep on cortisol secretion in response to ACTH and on cortisol and LH secretion in response to stress: importance of different stressors. Journal of Endocrinology 173 113-122. (https://doi.org/10.1677/joe.0.1730113)

Turner AI, Hosking BJ, Parr RA \& Tilbrook AJ 2006 A sex difference in the cortisol response to tail docking and ACTH develops between 1 and 8 weeks of age in lambs. Journal of Endocrinology 188 443-449. (https:// doi.org/10.1677/joe.1.06328)

Turner AI, Rivalland ET, Clarke IJ \& Tilbrook AJ 2010 Stressor specificity of sex differences in hypothalamo-pituitary-adrenal axis activity: cortisol responses to exercise, endotoxin, wetting, and isolation/ restraint stress in gonadectomized male and female sheep. Endocrinology 151 4324-4331. (https://doi.org/10.1210/en.2010-0234)

van Baak MA 2008 Meal-induced activation of the sympathetic nervous system and its cardiovascular and thermogenic effects in man. Physiology and Behavior 94 178-186. (https://doi.org/10.1016/j. physbeh.2007.12.020)

van Marken Lichtenbelt WD, Vanhommerig JW, Smulders NM, Drossaerts JMAFL, Kemerink GJ, Bouvy ND, Schrauwen P \& Jaap Teule GJ 2009 Cold activated brown adipose tissue in healthy men. New England Journal of Medicine 360 1500-1508. (https://doi. org/10.1056/NEJMoa0808718)

Verty AN, Allen AM \& Oldfield BJ 2010 The endogenous actions of hypothalamic peptides on brown adipose tissue thermogenesis in the rat. Endocrinology 151 4236-4246. (https://doi.org/10.1210/ en.2009-1235)

Vosselman MJ, van der Lans AA, Brans B, Wierts R, van Baak MA, Schrauwen P \& van Marken Lichtenbelt WD 2012 Systemic betaadrenergic stimulation of thermogenesis is not accompanied by brown adipose tissue activity in humans. Diabetes $613106-3113$ (https://doi.org/10.2337/db12-0288)

Walden TB, Hansen IR, Timmons JA, Cannon B \& Nedergaard J 2012 Recruited vs. nonrecruited molecular signatures of brown, "brite," and white adipose tissues. American Journal of Physiology: Endocrinology and Metabolism 302 E19-E31. (https://doi.org/10.1152/ ajpendo.00249.2011)

Walker SE, Zanoletti O, Guillot de Suduiraut I \& Sandi C 2017 Constitutive differences in glucocorticoid responsiveness to stress are related to variation in aggression and anxiety-related behaviors. Psychoneuroendocrinology 84 1-10. (https://doi.org/10.1016/j. psyneuen.2017.06.011)

Wang QA, Tao C, Gupta RK \& Scherer PE 2013 Tracking adipogenesis during white adipose tissue development, expansion and regeneration. Nature Medicine 19 1338. (https://doi.org/10.1038/ nm.3324)

Weiner J, Hankir M, Heiker JT, Fenske W \& Krause K 2017 Thyroid hormones and browning of adipose tissue. Molecular and Cellular Endocrinology 458 156-159. (https://doi.org/10.1016/j. mce.2017.01.011)

Wijers SL, Saris WH \& van Marken Lichtenbelt WD 2010 Cold-induced adaptive thermogenesis in lean and obese. Obesity 18 1092-1099. (https://doi.org/10.1038/oby.2010.74)

Wijers SL, Schrauwen P, van Baak MA, Saris WH \& van Marken Lichtenbelt WD 2011 Beta-adrenergic receptor blockade does not inhibit cold-induced thermogenesis in humans: possible involvement of brown adipose tissue. Journal of Clinical Endocrinology and Metabolism 96 E598-E605. (https://doi.org/10.1210/jc.2010-1957)

Wijers SLJ, Schrauwen P, Saris WHM \& van Marken Lichtenbelt WD 2008 Human skeletal muscle mitochondrial uncoupling is associated with 
cold induced adaptive thermogenesis. PLoS ONE 3 e1777. (https://doi. org/10.1371/journal.pone.0001777)

Williams KW, Margatho LO, Lee CE, Choi M, Lee S, Scott MM, Elias CF \& Elmquist JK 2010 Segregation of acute leptin and insulin effects in distinct populations of arcuate proopiomelanocortin neurons. Journal of Neuroscience 30 2472-2479. (https://doi.org/10.1523/ JNEUROSCI.3118-09.2010)

Wing RR \& Hill JO 2001 Successful weight loss maintenance. Annual Review of Nutrition 21 323-341. (https://doi.org/10.1146/annurev. nutr.21.1.323)

Wing RR \& Phelan S 2005 Long-term weight loss maintenance. American Journal of Clinical Nutrition 82 222S-225S. (https://doi.org/10.1093/ ajcn/82.1.222S)

Wu J, Bostrom P, Sparks LM, Ye L, Choi JH, Giang AH, Khandekar M, Virtanen KA, Nuutila P, Schaart G, et al. 2012 Beige adipocytes are a distinct type of thermogenic fat cell in mouse and human. Cell $\mathbf{1 5 0}$ 366-376. (https://doi.org/10.1016/j.cell.2012.05.016)

Yoneshiro T, Ogawa T, Okamoto N, Matsushita M, Aita S, Kameya T, Kawai Y, Iwanaga T \& Saito M 2012 Impact of UCP1 and $\beta 3 A R$ gene polymorphisms on age-related changes in brown adipose tissue and adiposity in humans. International Journal of Obesity 37 993. (https:// doi.org/10.1038/ijo.2012.161)
Yoshida K, Li X, Cano G, Lazarus M \& Saper CB 2009 Parallel preoptic pathways for thermoregulation. Journal of Neuroscience $\mathbf{2 9}$ 11954-11964. (https://doi.org/10.1523/JNEUROSCI.2643-09.2009)

Yu S, Qualls-Creekmore E, Rezai-Zadeh K, Jiang Y, Berthoud HR, Morrison CD, Derbenev AV, Zsombok A \& Münzberg H 2016 Glutamatergic preoptic area neurons that express leptin receptors drive temperature-dependent body weight homeostasis. Journal of Neuroscience 36 5034-5046. (https://doi.org/10.1523/ JNEUROSCI.0213-16.2016)

Yu Y, Deng C \& Huang X-F 2009 Obese reversal by a chronic energy restricted diet leaves an increased Arc NPY/AgRP, but no alteration in POMC/CART, mRNA expression in diet-induced obese mice. Behavioural Brain Research 205 50-56. (https://doi.org/10.1016/j. bbr.2009.07.003)

Zhang W, Sunanaga J, Takahashi Y, Mori T, Sakurai T, Kanmura Y \& Kuwaki T 2010 Orexin neurons are indispensable for stress-induced thermogenesis in mice. Journal of Physiology 588 4117-4129. (https:// doi.org/10.1113/jphysiol.2010.195099)

Zhao Z-D, Yang WZ, Gao C, Fu X, Zhang W, Zhou Q, Chen W, Ni X, Lin J-K, Yang J, et al. 2017 A hypothalamic circuit that controls body temperature. PNAS 114 2042-2047. (https://doi.org/10.1073/ pnas.1616255114)

Received in final form 27 March 2018

Accepted 5 April 2018
๑) 2018 Society for Endocrinology Published by Bioscientifica Ltd. Printed in Great Britain 